\title{
DISCIPLINE AND WORK ENVIRONMENT AFFECT EMPLOYEE PRODUCTIVITY: EVIDENCE FROM INDONESIA
}

\author{
Indra Prasetyo, Universitas Wijaya Putra, Akademi Sekretari dan \\ Manajemen Indonesia \\ Nabilah Aliyyah, Universitas Wijaya Putra, Akademi Sekretari dan \\ Manajemen Indonesia \\ Rusdiyanto, Universitas Airlangga Indonesia, Universitas Gresik \\ Chamariah, Universitas Wijaya Putra \\ Ramon Syahrial, Akademi Sekretari dan Manajemen Indonesia \\ Diah Rani Nartasari, Akademi Sekretari dan Manajemen Indonesia \\ Yuventius, Akademi Sekretari dan Manajemen Indonesia \\ Hadi Wibowo, Akademi Sekretari dan Manajemen Indonesia \\ Sanjayanto, Akademi Sekretari dan Manajemen Indonesia \\ Sulistiyowati, Akademi Sekretari dan Manajemen Indonesia
}

\begin{abstract}
Objective: This paper aims to test and evaluate the Effect of Discipline And Work Environment on Employee Productivity of state-owned public bodies.

Design/methodology/approach: This paper uses a quantitative approach using a survey approach. The survey is a study conducted on the employee population of state-owned public agency companies, samples taken from the employee population of state-owned public agency companies to find events related to discipline variables and work environments that can affect employee productivity variables, to analise the influence between discipline variables and the work environment on employee productivity variables using a statistic regression approach. This method is used to explain the influence of discipline variables and work environment on employee productivity variables. This approach is simply to provide a description and test the influence between discipline variables and the work environment on employee productivity variables that can be known how much the influence of discipline variables and work environment on employee productivity variables.

Findings: The findings of this study explain that discipline has an influence on the productivity of employees of publicly owned companies, the work environment has an influence on the productivity of employees of publicly owned companies, while together discipline and work environment have an influence on the productivity of employees of publicly owned companies.

Practical Implications: The results of the study are recommended for employees to improve the effectiveness and efficiency of the performance of state-owned public bodies.

Originality: Previous research conducted to test the influence of discipline and work environment on the productivity of employees of manufacturing companies listed on the Indonesia Stock Exchange, the findings concluded that discipline and work environment have an influence on the work productivity of employees of manufacturing companies listed on the Indonesia Stock Exchange. This research object of research on publicly owned companies owned by the state.
\end{abstract}


Keywords: Discipline, Work Environment, Productivity

\section{INTRODUCTION}

Human beings, as one of the production factors, provide resources that are very instrumental in achieving the company's goals. Efficient and effectiveness of a company is very dependent on the poor development of human resources in the company, because of the importance of human resources (Alsaghir et al., 2020; Baradaran \& Hosseinian, 2020; Erna, 2020; Gadomska-Lila, 2020; Revillot-Narváez et al., 2020; Sato et al., 2020). The human resources must get attention to be utilized optimally (Bhatt \& Bahuguna, 2019; Karimi \& Taghaddos, 2020; Meng et al., 2019; No Title, n.d.; Syarifuddin \& Damayanti, 2019; Zakariya et al., 2019; Zhang \& Nesbit, 2018).

Productivity is the main demand for the company so that its survival or operation can be achieved (Cury \& Saraiva, 2018; Dangelico, 2016; Nguyen et al., 2019; Oey et al., 2020; T. Singh \& Malhotra, 2020; Stojanov \& Ding, 2015). Many things can affect work productivity; therefore, companies must try to ensure that productivity factors can be met to the maximum. One of the factors that affect is discipline (Cruz et al., 2012; Dal et al., 2013; Lin et al., 2012; Malakauskaite \& Navickas, 2010; Mamun et al., 2012; Mikalauskas et al., 2013).

The discipline of work is very important because, without the discipline of work, every job will not be completed properly (Abell \& Sevian, 2020; ĐorĎević, 2020; Lund et al., 2020; Mphatheni et al., 2020; Richter et al., 2020; Serebryakov, 2020). Thus it is undeniable that work discipline is the determining factor of success in a company; if the discipline of work is ignored will hinder and harm the company (Busta \& Russo, 2020; Charity Hudley et al., 2020; Hu \& Liu, 2020; Martino, 2020; Rodriguez et al., 2020; Wang et al., 2020). Because without discipline, it will decrease employee performance so that the company's target will not be achieved (Björkhagen Turesson, 2020; Farley-Ripple et al., 2020; Fitzgerald \& Jiang, 2020; Martimianakis et al., 2020; Millstein et al., 2020; Rodríguez-Araya et al., 2020).

The work environment has an influence on the performance of the company's employees to complete the tasks charged to him that ultimately affect the work productivity of employees, a good environment will improve work, and vice versa if the work environment is less calm, will be able to increase the level of mistakes they make (Cassely et al., 2020; Husin \& Kernain, 2020; Rameshwar et al., 2020; Rodrigo-Alarcón et al., 2020; Saleh et al., 2020; Szlang \& Bruch, 2020).

To realize high work productivity, every employee and every work unit works as it should (Lorenzo, 2001). Thus, every employee must have a good work commitment and try to work effectively to realize the work directed at achieving the company's goals (Anguelov et al., 2020; Ingsih et al., 2017; Othman et al., 2019; Prasad \& Sana, 2020; Purohit, 2018; Stombelli, 2020).

This study identified problems relevant to this study, among others: There are still employees who are late for work after lunch hours, less supportive work environment, for example, lack of lighting in the workspace, noisy workplace atmosphere, as well as facilities and infrastructure that are not by the number of employees, employees are less in getting training so that their productivity tends to decrease and impact on the lack of services provided to employees, Decreased employee work productivity is caused by a lot of employees who work casually and lack discipline in the absence of supervision from the leadership, still, low employee workability caused by the lack of training provided by the company to employees. 


\section{LITERATURE REVIEW AND HYPOTHESIS DEVELOPMENT}

\section{Human Resource Management}

Human Resource Management is a human labour problem that is organized according to the order of its functions, to be effective and efficient in realizing the objectives of the office, employees and society (Ahn \& Huang, 2020; Bianchi et al., 2020; Gulzar et al., 2020; Halliru et al., 2020; Wolff et al., 2020; Xu et al., 2020). Employees are planners and actors who always play an active role in every company's activity (Ahmad \& Chowdhury, 2020; Choudhury et al., 2020; Condé \& Martens, 2020; Cooke et al., 2020; Oluwatayo \& Adetoro, 2020; Xiao et al., 2020). Stated personnel management is a science to carry out, among others: Planning, Organizing and Controlling so that the effectiveness and function of personnel can be improved as much as possible in achieving goals (Ahmad \& Chowdhury, 2020; Choudhury et al., 2020; Condé \& Martens, 2020; Cooke et al., 2020; Oluwatayo \& Adetoro, 2020; Xiao et al., 2020).

To achieve the goals that have been set it is necessary to know the four objectives of human resource management (Ellison, 2013; Narayana Swamy \& Nagaraju, 2016) namely: a) Personal goals of company members, b) Objectives of society as a whole, c) The purpose of the company in the sense of the objectives of human resource management and d) Functional objectives.

Internal factors of human resource management planning Development, Budget or Financing, Agency Design, Expansion of Institution Activities, etc. External Factors include Economic, Socio-Political and Cultural, Law and Regulation, Development of Science and Technology, and Competition Between Companies (Kanitvittaya et al., 2010; Longo, 2007; Mateescu et al., 2017).

In general, the understanding of human resources can be examined from a macro scale (Dartey-Baah et al., 2020; Jang et al., 2020; Kögel \& Wolbring, 2020; Martdianty et al., 2020; Sangwan et al., 2020; A. Valenti \& Horner, 2020), where human resources are defined as "The overall potential of labour contained in a country (Daanaa et al., 2020; Ou et al., 2018; Reiner et al., 2019; Subramanien \& Joseph, 2019; M. Valenti et al., 2019; Volodko et al., 2020). While on a micro-scale is only interpreted "A group of people who meet the needs of their lives by working in corporate units both government and private (Abraham \& Seyyed, 2012; Horvat, 2009; ISBARY, 1962; Manohar, 2013; Prashar, 2019).

Human resource management is planning, companies, directing and supervising the procurement, development, compensation, integration, maintenance and determination of working relationships to help to achieve the goals of the company, individuals and communities (Harris et al., 2011; Järvenpää, 2007) Human resource management is a science and art that regulates the relationships and roles of the workforce to be effective and efficient in helping the realization of the goals of the company, employees and society (S. R. Taylor \& Weiss, 2009). Human resource management is the withdrawal, selection, development, maintenance, use of human resources to achieve both individual and corporate goals (Thakur, 1999).

In Indonesia, human resource management is very important (Harini et al., 2020; Martdianty et al., 2020; Prasetyo et al., 2020; Savitri et al., 2020; Wolor et al., 2020; Yusuf, 2020). However, our country is rich in natural resources and began to develop advanced technologies (Masik \& Studzińska, 2018; Saldaña, 2006). All of them can not be utilized 
effectively and efficiently if not supported by human resources with good quality ability in the right amount and time (Pérez et al., 2015; Stubbs, 2016).

\section{Discipline}

The sense of discipline in a narrow sense means punishing. This sense becomes common, so that it means negative (Kozorez et al., 2020; No Title, n.d.; Ouyang et al., 2020; Richter et al., 2020; Serebryakov, 2020; Sun et al., 2020). The word discipline comes from Latin; discipline means exercise or education (Wilson, 2010). From forming discipline derived from the verb discere, meaning teaching, then disciplinary means teaching, educating and expanding (Chen et al., 2020; Cubero et al., 2020; Deane, 2020; Guan et al., 2020; Hong \& Basturkmen, 2020; Teasdale et al., 2020).

Discipline is obedience to institutions or companies and everything that becomes its provisions without using feelings (Dwiartama, 2018), based only on conversion and awareness that without such obedience everything that becomes the provisions or objectives of the company will not be achieved (Abdullah et al., 2018; da Costa et al., 2019; Mita et al., 2018; S. Singh et al., 2020; Suhud et al., 2019; Thamagasorn \& Pharino, 2019).

Stated that what is meant by discipline is an effort made to create a state in an orderly (Alter et al., 2020; Haghani \& Bliemer, 2020; Ji et al., 2020; Johnston, 2020; Martino, 2020; Sun et al., 2020), effective and successful work environment through an appropriate system (Engelbrecht, 2009; Guo, 2010; Jones et al., 2010; Klimoviene et al., 2016; Nikolou-Walker \& Curley, 2012; Yaghoubi et al., 2018).

\section{Work Environment}

The work environment is an environment where employees do their daily work". A conducive work environment provides a sense of security and allows employees to be able to work optimally (Afanasyev et al., 2020; Idoko et al., 2020; Revin et al., 2020; Reyes Romero et al., 2020; Tryma et al., 2020; Turanina et al., 2020). The work environment can affect an employee's emotions. If the employee enjoys the work environment in which he/she works, the employee will feel at home in his/her workplace to do activities so that work time is used effectively and optimistic employees' work performance is also high (Alhamda et al., 2020; Alzamel et al., 2020; Chalikias et al., 2020; Gulzar et al., 2020; Liao et al., 2020; Riyadi et al., 2020). The work environment includes established working relationships between fellow employees and employment relationships between subordinates and superiors and the physical environment in which employees work (Achu Ayuk et al., 2020; Bove, 2020; Collier-Bordet et al., 2020; Rizova et al., 2020; Tsitsovits, 2020; Victoria \& Ortigosa, 2020).

The work environment is everything around the workers that can influence him in carrying out the tasks carried out (Cooper et al., 2020; D“Intino et al., 2020; Mylona \& Mihail, 2020; Sarro et al., 2020; Silva-Romo et al., 2020; Velicu \& Barca, 2020). The work environment is: "Tools and materials faced, the surrounding environment in which a person works, his working methods, as well as working arrangements both as an individual and as a group" (Apaolaza et al., 2020; Busta \& Russo, 2020; Mackert et al., 2020; Pogodziński et al., 2020; Sampson et al., 2020; Susanto, 2020).

Based on the description of the definitions above, it can be concluded that the work environment is an environment in which the employees work in both physical and non-physical 
forms that can affect employees in carrying out their duties. Thus, the company must strive to create a new work environment to show their full potential, as workers and people.

\section{Work Productivity}

Productivity contains two meanings, namely philosophical understanding and technical understanding (Degtyarev et al., 2020; Gubarenko et al., 2020; Kulikova et al., 2020; Schnabel, 2020; Serebryakova et al., 2020; A. Taylor, 2020). Philosophically, the notion of productivity basically includes a mental attitude that has always believed that this life and way of working should be better than yesterday's life and way of working, and the results achieved tomorrow should be more or better than those obtained today. Thus, productivity contains a sense of relative improvement; this opinion was expressed by (Brombin et al., 2020; Lackie \& Tomblin Murphy, 2020; Muazzam et al., 2020; Setiadi et al., 2020; Toscano \& Zappalà, 2020; Yoshimoto et al., 2020)

Defines productivity as follows: "Productivity is the relationship between the quality produced and the amount of work done to achieve these results (Fischer et al., 2020; Gaillard et al., 2020; Gu et al., 2020; Peprah et al., 2020; Vaithyasubramanian et al., 2020; Vidaković et al., 2020). Provides a general sense of productivity is a universal concept aiming to provide more goods, services and people by using fewer rill sources. Productivity is an interdisciplinary approach to determining effective objectives, plan making, and production methods to use sources efficiently while maintaining high quality (Giacalone et al., 2020; Hill \& Schmutz, 2020; Jilcha Sileyew, 2020; Nascimento \& Lopes, 2020; Schneider, 2020; Vasiljeva et al., 2020).

Revealed that labour productivity is measured based on performance, commonly called work achievement, but this term is very misleading (Dawit et al., 2020; Ghosh \& Seethamraju, 2020; Haynes et al., 2020; Muyombano \& Espling, 2020; Tuor Sartore \& Backes-Gellner, 2020; Wiedman, 2020). Performance is none other than the value of an employee's behaviour towards the role function, activities, and tasks demanded by the position's requirements (job requirements). These three components of work must be seen in terms of procedures and work companies (Alluhidan et al., 2020; Brown et al., 2020; Fanego, 2020; Liogier, 2020; PamiesBertrn \& Yuan, 2020; Ribeiro et al., 2020). So performance is the resultant of the function of position requirements and procedures/company work. If the existing work requirements are completed with procedures and the Company's work is not steady, then the performance will be affected, and vice versa.

Based on the explanation above on work productivity, the author concluded that productivity is an effort to use and save costs or efficiency of using all resources needed to achieve certain results or objectives optimally.

\section{Research Framework}

Human beings have infinite needs, and we consciously or not will always meet those needs to achieve satisfaction. If a need is not met, it will cause tension, and this will cause unrest in the company. If these difficulties are not resolved quickly, it will result in a decrease in the level of employee productivity. The onset of tension is also caused by a feeling of a need that is getting a higher intensity level so that it turns into a desire. This desire is regarded as a specific way of being affected by the environment with which those needs will be met. One way to increase the employee's work productivity is with good discipline and provide a good working environment. 
To provide thought flow in this research, try to explain the frame of thought of research. Where the purpose of the research to be achieved is to know the influence of discipline and work environment on employee productivity. The frame of thought can be seen in the following Figure 1.

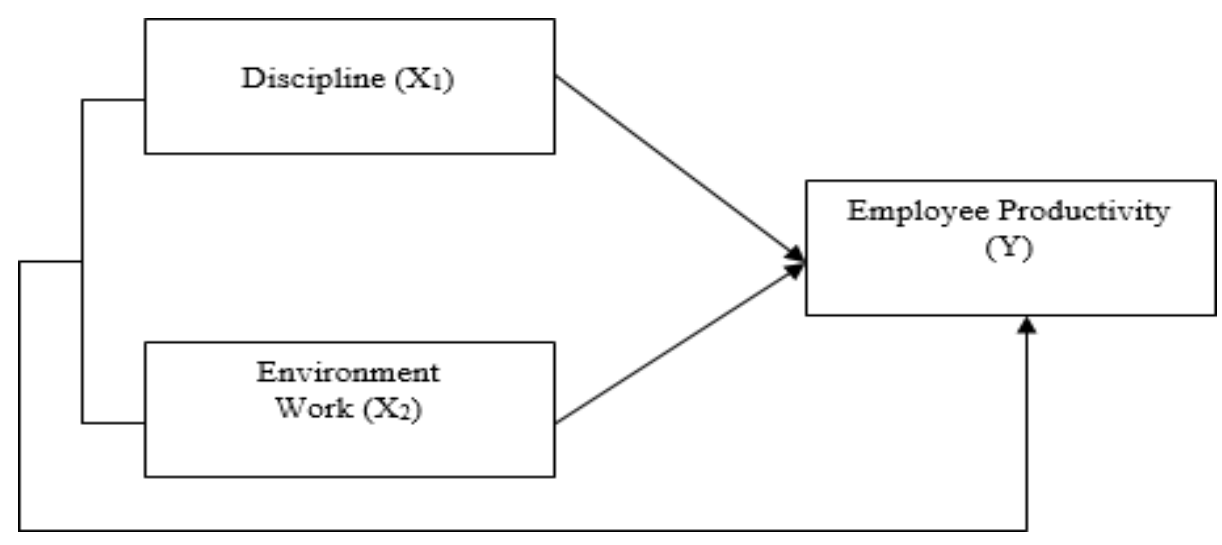

\section{Figure 1}

RESEARCH FRAMEWORK

\section{Hypothesis}

Hypotheses mean statements. Thus hypotheses mean weak statements, so-called because they are still untested conjectures (Canel et al., 2017; Forte et al., 2017; Zhylenko et al., 2019). The research hypothesis is: "Research using quantitative approaches. In qualitative research, hypotheses are not formulated, but it is expected that hypotheses can be found. Furthermore, the hypothesis will be tested by researchers using quantitative approaches."

Based on the statement above, it can be concluded that the research hypothesis can be interpreted as a temporary answer to research problems, until proven through the collected data and must be tested empirically.

1. There is a disciplined influence on employee productivity in publicly owned companies.

2. There is an influence of the work environment on employee productivity in publicly owned companies

3. There is an influence of discipline and work environment on employee productivity in publicly owned companies.

\section{RESEARCH METHODOLOGY}

\section{Research Design}

This research uses a survey approach. The survey is a study conducted on the employee population of state-owned public agency companies, samples taken from the employee population of state-owned public agency companies to find events related to discipline variables and work environments that can affect employee productivity variables, to analyse the influence between discipline variables and the work environment on employee productivity variables using a statistic regression approach (Juanamasta et al., 2019; Prabowo et al., 2020; Rusdiyanto, Agustia, et al., 2020; Rusdiyanto, Hidayat, et al., 2020; Syafii et al., 2020). This method is used 
to explain the influence of discipline variables and work environment on employee productivity variables. This approach provides a description and tests the influence between discipline variables and the work environment on employee productivity variables that can be known how much influence discipline variables and work environment on employee productivity variables.

\section{Research Variables}

Discipline is an effort to create an orderly, effective and successful working environment through an appropriate system (Table 1).

\begin{tabular}{|c|c|c|c|}
\hline \multicolumn{4}{|c|}{$\begin{array}{c}\text { Table 1 } \\
\text { DISCIPLINE RESEARCH VARIABLE QUESTIONNAIRE GRID }\end{array}$} \\
\hline Variable & Dimensions & Indicators & Item Quest \\
\hline \multirow{14}{*}{ Discipline (X1) } & \multirow{6}{*}{ Mental attitude } & Sincerity of heart & 1 \\
\hline & & Work spirit & 2 \\
\hline & & Applicable terms & 3 \\
\hline & & Punitive sanction & 4 \\
\hline & & Arrive on time & 5 \\
\hline & & To be an example & 6 \\
\hline & \multirow{5}{*}{ Good understanding } & Full of dedication & 7 \\
\hline & & Have a commitment & 8 \\
\hline & & Have responsibilities & 9 \\
\hline & & Got to be nice. & 10 \\
\hline & & Must behave according to the rules & 11 \\
\hline & \multirow{3}{*}{ Good attitude } & Loyalty at work & 12 \\
\hline & & Must be sensitive & 13 \\
\hline & & Gotta be fair & 14 \\
\hline
\end{tabular}

The work environment is a whole system of ideas, actions and workplace atmosphere that will impact the performance of personnel in an organization (Table 2).

\begin{tabular}{|c|c|c|c|}
\hline \multicolumn{4}{|c|}{$\begin{array}{c}\text { Table } 2 \\
\text { DISCIPLINE RESEARCH VARIABLE QUESTIONNAIRE GRID }\end{array}$} \\
\hline Variable & Dimensions & Indicators & $\begin{array}{l}\text { Item } \\
\text { Quest }\end{array}$ \\
\hline \multirow{7}{*}{$\begin{array}{c}\text { Work Environment } \\
\text { (X2) }\end{array}$} & \multirow{6}{*}{ Work environment factors } & The light & 1 \\
\hline & & Temperature & 2 \\
\hline & & Air circulation & 3 \\
\hline & & Mechanical vibration & 4 \\
\hline & & Ac usage & 5 \\
\hline & & Set the color & 6 \\
\hline & Work environment & Decoration & 7 \\
\hline
\end{tabular}




\begin{tabular}{|l|l|c|}
\multirow{5}{*}{ indicators } & Music at work & 8 \\
\cline { 2 - 3 } & Sufficient lighting & 10 \\
\cline { 2 - 3 } & Sufficient air exchange & 11 \\
\cline { 2 - 3 } & Quiet work environment & 12 \\
\cline { 2 - 3 } & Noise & 13 \\
\cline { 2 - 3 } & Large wiggle room & 14 \\
\cline { 2 - 3 } & Guarantee of security & 15 \\
\hline
\end{tabular}

Productivity is an interdisciplinary approach to determining effective objectives, plan making, and production methods to use sources efficiently while maintaining high quality (Table 3).

\begin{tabular}{|c|c|c|c|}
\hline WORK I & DDUCTIVITY RESEA & RIABLE QUESTIONN & RID \\
\hline Variable & Dimensions & Indicators & Item Quest \\
\hline \multirow{13}{*}{ Productivity (Y) } & \multirow{4}{*}{ Utilization } & Skills & 1 \\
\hline & & Technology & 2 \\
\hline & & Management & 3 \\
\hline & & Works & 4 \\
\hline & \multirow{4}{*}{ Non Physical Aspects } & Organizational system & 6 \\
\hline & & Incentive system & 7 \\
\hline & & Security & 8 \\
\hline & & Work safety & 9 \\
\hline & \multirow{5}{*}{ Institutional Factors } & Concentration & 10 \\
\hline & & Behavior & 11 \\
\hline & & Attitude & 12 \\
\hline & & Motivation & 13 \\
\hline & & Key factors & 14 \\
\hline
\end{tabular}

\section{Population and Sample}

The population is a generalization area consisting of objects or subjects with the quantity and characteristics that researchers apply to be studied and then drawn conclusions. The population and samples in this study are the objects/subjects studied. Still, they include all the characteristics/traits possessed by the subject or object where the population and sample of 280 people. 


\section{Data Collection Techniques}

This study uses data obtained from organizations on the influence of discipline and work environment on the productivity of employees of state-owned public companies. This research technique is carried out by going directly to the field by using questionnaire data collection tools, namely data collection techniques by presenting questions in writing to respondents, questionnaires are cooperative, it is expected that cooperation in time allowance and answering questions in writing according to the instructions the author provides.

In the questionnaire that will be distributed to the respondent, contains several answers to existing questions. The answer is divided into 5 (five) categories, namely:

$\begin{array}{ccc}\text { SS }= & & \\ \text { Strongly } & \text { Value } & 5 \\ \text { Agree } & & \\ \text { S }=\text { Agree } & \text { Value } & 4 \\ & & \\ \text { KS }= & \text { Value } & 3 \\ \text { Disagreeing } & & \\ \text { TS }= & \text { Value } & 2 \\ \text { Disagree } & & \\ \text { STS }= & & \\ \text { Strongly } & \text { Value } & 1 \\ \text { Disagree } & & \\ & & \end{array}$

\section{RESEARCH AND DISCUSSION RESULTS}

\section{Research Results}

Discipline Variables have 3 dimensions, 15 indicators, 15 statements (questionnaires) with ordinal scale measured with answers 5=Strongly Agree, 4=Agree, 3=Disagree, 2=Disagree, $1=$ Strongly Disagree. The following is the distribution of questionnaire answer results for discipline variables:

$\begin{array}{ccc}(24,77) & \begin{array}{c}\text { Respondents } \\ \text { strongly } \\ \text { agree }\end{array} & \text { score275 } \\ & \text { Respondents } \\ \text { Agree } & \text { score457 } \\ & & \\ (27,84) & \begin{array}{c}\text { Respondents } \\ \text { Disagreeing }\end{array} & \text { score309 } \\ & & \\ (5,59) & \begin{array}{c}\text { Respondents } \\ \text { Disagree }\end{array} & \text { score62 }\end{array}$


$(0,63) \quad \begin{gathered}\text { Respondents } \\ \text { Strongly } \\ \text { Disagree }\end{gathered} \quad$ score7

\begin{tabular}{|c|c|c|c|c|c|c|}
\hline \multicolumn{7}{|c|}{$\begin{array}{c}\text { Table } 4 \\
\text { FREQUENCY OF ASSESSMENT SCORE AND \% OF RESPONDENTS' } \\
\text { STATEMENTS AGAINST DISCIPLINE VARIABLES (X1) }\end{array}$} \\
\hline \multirow{2}{*}{ Statement } & \multicolumn{6}{|c|}{ RATING SCORE AND \% STATEMENT } \\
\hline & STS & TS & KS & $\mathbf{S}$ & SS & Total \\
\hline Discipline 1 & & 1 & 18 & 30 & 25 & 74 \\
\hline Discipline 2 & & 1 & 19 & 36 & 18 & 74 \\
\hline Discipline 3 & 1 & 3 & 17 & 35 & 18 & 74 \\
\hline Discipline 4 & 1 & 7 & 18 & 30 & 18 & 74 \\
\hline Discipline 5 & & 7 & 23 & 26 & 18 & 74 \\
\hline Discipline 6 & 1 & 9 & 18 & 27 & 19 & 74 \\
\hline Discipline 7 & & 6 & 28 & 26 & 14 & 74 \\
\hline Discipline 8 & & 5 & 29 & 30 & 10 & 74 \\
\hline Discipline 9 & 1 & 11 & 26 & 17 & 19 & 74 \\
\hline Discipline 10 & 1 & 3 & 17 & 32 & 21 & 74 \\
\hline Discipline 11 & & 1 & 20 & 28 & 25 & 74 \\
\hline Discipline 12 & & 1 & 20 & 36 & 17 & 74 \\
\hline Discipline 13 & & 3 & 26 & 30 & 15 & 74 \\
\hline Discipline 14 & 1 & 1 & 17 & 38 & 17 & 74 \\
\hline Discipline 15 & 1 & 3 & 13 & 36 & 21 & 74 \\
\hline Discipline & 7 & 62 & 309 & 457 & 275 & 1110 \\
\hline$\%$ & 0,63 & 5,59 & 27,84 & 41,17 & 24,77 & 100 \\
\hline
\end{tabular}

In the Table 4 above can be concluded from 74 samples studied, for disciplinary variables from 15 statements presented respondents' answers that often appear is the answer "agree" is as much as 457 times or $41.17 \%$. Respondents' answers can also be presented in the form of histograms or bar charts as below Figure 2.

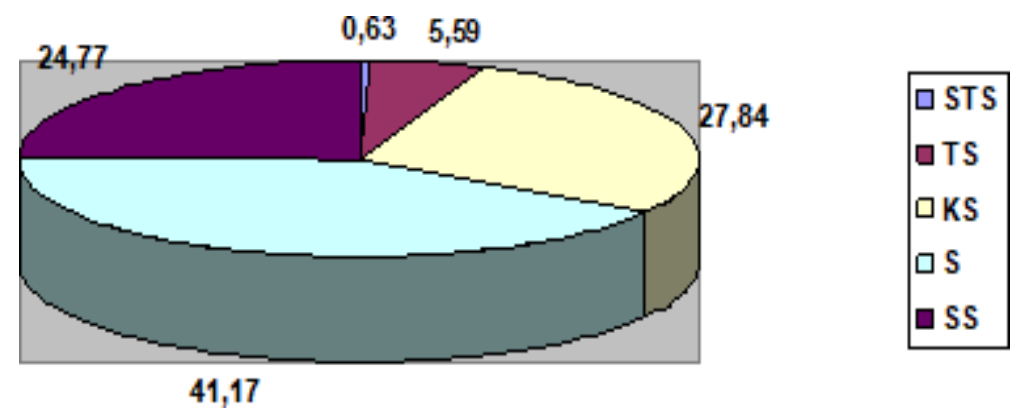

FIGURE 2

\% FREQUENCY OF RESPONDENTS TO DISCIPLINARY VARIABLE STATEMENTS

From the diagram above, it can be found that as many as $41.17 \%$ of respondents said they agree with discipline on employee productivity. The spread of questionnaires for discipline variable data showed that the lowest score was 30 , and the highest score was 70 . Thus, obtaining the lowest and highest score, the range is 40 (70 - 30). The figures after being analyzed resulted in: 


\section{Mean : \\ 57.5811 \\ Standar \\ Deviasi : \\ 7.90354}

Range : 40

Minimum :

30

Maksimum

: 70 follows:

To describe the frequency of data is presented in the form of frequency distribution as

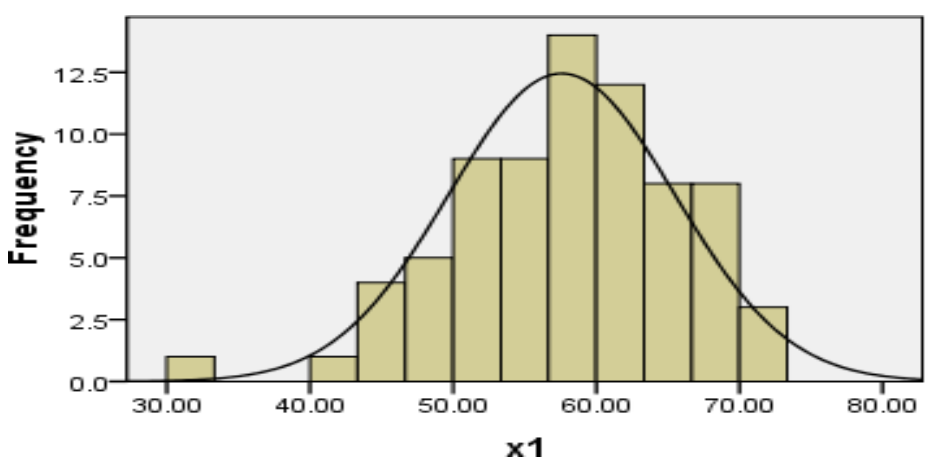

$$
\begin{gathered}
\text { Mean }=57.58 \\
\text { Std. Dev }=7.904 \\
N=74
\end{gathered}
$$

Figure 3

DISCIPLINE VARIABLE HISTOGRAM GRAPH (X1)

Work environment variables have 2 dimensions, 15 indicators, 15 statements (questionnaires) (Figure 3) with ordinal scale measured with answers 5=Strongly Agree, 4=Agree, 3=Disagree, 2=Disagree, 1=Strongly Disagree. The following is the distribution of questionnaire answer results for work environment variables:

\begin{tabular}{|c|c|c|}
\hline$(27,66)$ & $\begin{array}{l}\text { Respondents } \\
\text { strongly } \\
\text { agree }\end{array}$ & $\begin{array}{c}\text { score } \\
307\end{array}$ \\
\hline$(36,76)$ & $\begin{array}{l}\text { Respondents } \\
\text { Agree }\end{array}$ & $\begin{array}{c}\text { score } \\
408\end{array}$ \\
\hline$(26,66)$ & $\begin{array}{l}\text { Respondents } \\
\text { Disagreeing }\end{array}$ & $\begin{array}{c}\text { score } \\
296\end{array}$ \\
\hline$(7,39)$ & $\begin{array}{l}\text { Respondents } \\
\text { Disagree }\end{array}$ & $\begin{array}{l}\text { score } \\
87\end{array}$ \\
\hline$(1,53)$ & $\begin{array}{l}\text { Respondents } \\
\text { Strongly } \\
\text { Disagree }\end{array}$ & $\begin{array}{c}\text { score } \\
17\end{array}$ \\
\hline
\end{tabular}


Table 5

FREQUENCY OF ASSESSMENT SCORE AND \% OF RESPONDENTS' STATEMENTS ON WORK ENVIRONMENT VARIABLES (X2)

\begin{tabular}{|c|c|c|c|c|c|c|}
\hline \multirow{2}{*}{ Statement } & \multicolumn{6}{|c|}{ RATING SCORE AND \% STATEMENT } \\
\hline & STS & TS & STS & $\mathbf{S}$ & STS & Total \\
\hline LK 1 & 1 & 7 & 27 & 22 & 17 & 74 \\
\hline LK 2 & 3 & 2 & 17 & 25 & 27 & 74 \\
\hline LK 3 & 1 & 8 & 15 & 19 & 31 & 74 \\
\hline LK 4 & 1 & 2 & 13 & 35 & 23 & 74 \\
\hline LK 5 & 2 & 3 & 12 & 36 & 21 & 74 \\
\hline LK 6 & & 5 & 25 & 22 & 22 & 74 \\
\hline LK 7 & 1 & 9 & 17 & 28 & 19 & 74 \\
\hline LK 8 & & 6 & 29 & 26 & 13 & 74 \\
\hline LK 9 & 2 & 5 & 32 & 28 & 7 & 74 \\
\hline LK 10 & 2 & 13 & 33 & 17 & 9 & 74 \\
\hline LK 11 & & 5 & 21 & 25 & 23 & 74 \\
\hline LK 12 & 1 & 3 & 13 & 30 & 27 & 74 \\
\hline LK 13 & 1 & 5 & 27 & 20 & 21 & 74 \\
\hline LK 14 & 1 & 5 & 4 & 36 & 28 & 74 \\
\hline LK 15 & 1 & 4 & 11 & 39 & 19 & 74 \\
\hline Work environment & 17 & 82 & 296 & 408 & 307 & 1110 \\
\hline$\%$ & 1,53 & 7,39 & 26,66 & 36,76 & 27,66 & 100 \\
\hline
\end{tabular}

In the Table 5 above can be concluded from 74 samples studied, for work environment variables from 15 statements presented respondents' answers that often appear is the answer "agree" is as much as 408 times or $36.76 \%$. Respondents' answers can also be presented in the form of histograms or bar charts such as below (Figure 4):

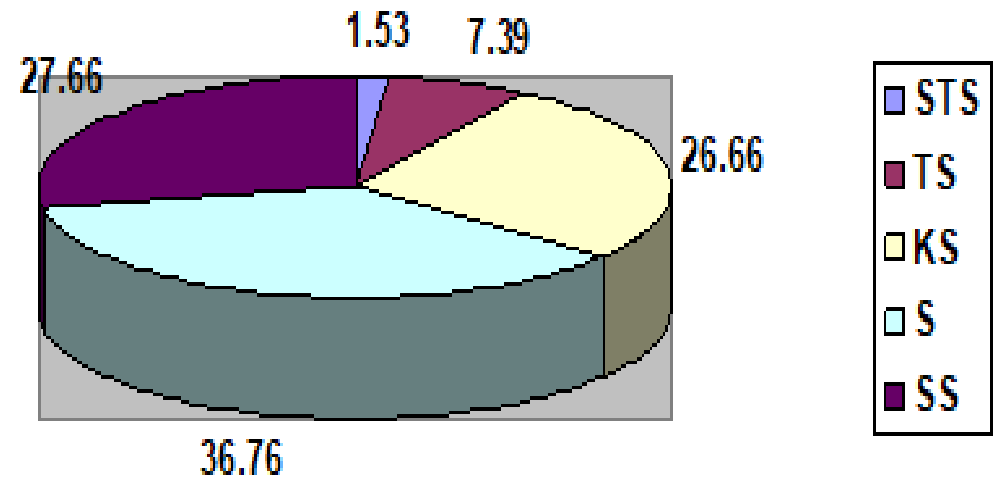

Figure 4

\% FREQUENCY OF RESPONDENTS TO WORK ENVIRONMENT VARIABLE STATEMENTS 
From the diagram above, it can be found that as many as $36.76 \%$ of respondents said they agree with the work environment on employee productivity.

The results of the questionnaire spread for work environment variable data showed that the lowest score was 31, and the highest score was 75. Thus, obtaining the lowest and highest score, the range is $44(71-31)$. The Figure 5 after being analyzed resulted in:

\section{Mean : \\ 57.2432 \\ Standar \\ Deviasi : \\ 9.11992 \\ Range : 44 \\ Minimum : \\ 31 \\ Maksimum \\ $: 75$} follows:

To describe the frequency of data is presented in the form of frequency distribution as

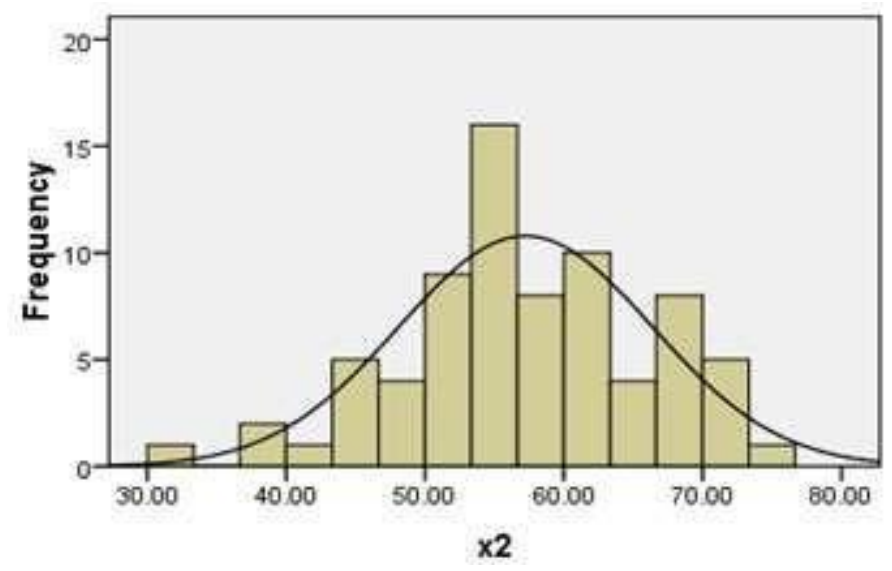

Mean $=57.24$
Std. Dev, $=9.12$

FIGURE 5

WORK ENVIRONMENT VARIABLE HISTOGRAM GRAPHIC (X2)

Employee productivity variables have 3 dimensions, 15 indicators, 15 statements (questionnaires) with ordinal scale measured by answers $5=$ Strongly Agree, $4=$ Agree, $3=$ Disagree, 2 = Disagree, $1=$ Strongly Disagree. The following is the distribution of questionnaire answer results for employee productivity variables:

$\begin{array}{ccc}(26,85) & \begin{array}{c}\text { Respondents } \\ \text { strongly } \\ \text { agree }\end{array} & \begin{array}{c}\text { score } \\ 298\end{array} \\ & \text { Respondents } & \text { score } \\ (36,85) & \begin{array}{c}\text { Agree } \\ 409\end{array}\end{array}$


$(24,23)$

Respondents score

Disagreeing 269

$\begin{array}{cc}\text { (8,74) } & \text { Respondents } \\ \text { Disagree } & \text { score }\end{array}$

$(3,33)$

Respondents score

Strongly $\quad 37$

Disagree

\begin{tabular}{|c|c|c|c|c|c|c|}
\hline \multicolumn{7}{|c|}{$\begin{array}{c}\text { Table } 6 \\
\text { FREQUENCY OF ASSESSMENT SCORE AND \% OF RESPONDENTS' STATEMENT ON } \\
\text { EMPLOYEE PRODUCTIVITY VARIABLES (Y) }\end{array}$} \\
\hline \multirow{2}{*}{ Statement } & \multicolumn{6}{|c|}{ RATING SCORE AND \% STATEMENT } \\
\hline & STS & TS & STS & $\mathbf{S}$ & STS & Total \\
\hline PK 1 & 2 & 10 & 18 & 26 & 18 & 74 \\
\hline PK 2 & 1 & 7 & 20 & 30 & 16 & 74 \\
\hline PK 3 & & 15 & 15 & 27 & 17 & 74 \\
\hline PK 4 & 1 & 9 & 33 & 19 & 12 & 74 \\
\hline PK 5 & & 2 & 20 & 33 & 19 & 74 \\
\hline PK 6 & & 6 & 34 & 26 & 8 & 74 \\
\hline PK 7 & 5 & 5 & 17 & 29 & 18 & 74 \\
\hline PK 8 & 5 & 5 & 10 & 21 & 33 & 74 \\
\hline PK 9 & 2 & 9 & 24 & 22 & 17 & 74 \\
\hline PK 10 & 5 & 2 & 7 & 22 & 38 & 74 \\
\hline PK 11 & 6 & 8 & 14 & 27 & 19 & 74 \\
\hline PK 12 & 5 & 3 & 14 & 29 & 23 & 74 \\
\hline PK 13 & 1 & 7 & 17 & 37 & 12 & 74 \\
\hline PK 14 & & 5 & 13 & 33 & 23 & 74 \\
\hline PK 15 & 4 & 4 & 13 & 28 & 25 & 74 \\
\hline Employee Productivity & 37 & 97 & 269 & 409 & 298 & 1110 \\
\hline$\%$ & 3,33 & 8,74 & 24,23 & 36,85 & 26,85 & 100 \\
\hline
\end{tabular}

In the Table 6 above can be concluded from 74 samples studied, for employee productivity variables from 15 statements presented respondents' answers that often appear is the answer "agree" that is as much as 409 times or $36.85 \%$. Respondents' answers can also be presented in the form of histograms or bar charts as below (Figure 6): 


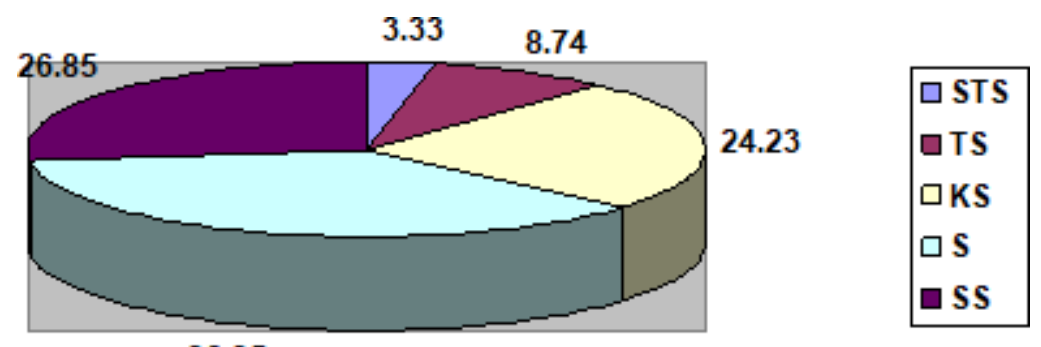

36.85

Figure 6

\% FREQUENCY OF RESPONDENTS TO EMPLOYEE PRODUCTIVITY VARIABLE

STATEMENTS

From the diagram above, it can be found that as many as $36.85 \%$ of respondents said they agree with discipline and work environment towards employee productivity.

The results of the questionnaire spread for employee productivity variable data showed that the lowest score was 26 , and the highest score was 74 . Thus, obtaining the lowest and highest score, the range is 48 (74 - 26). The figures after being analyzed resulted in:

Mean :
56.2703
Standar
Deviasi :
9.44820
Range : 48
Minimum :
26
Maksimum
$: 74$

To describe the frequency of data is presented in the form of frequency distribution as follows (Figure 7):

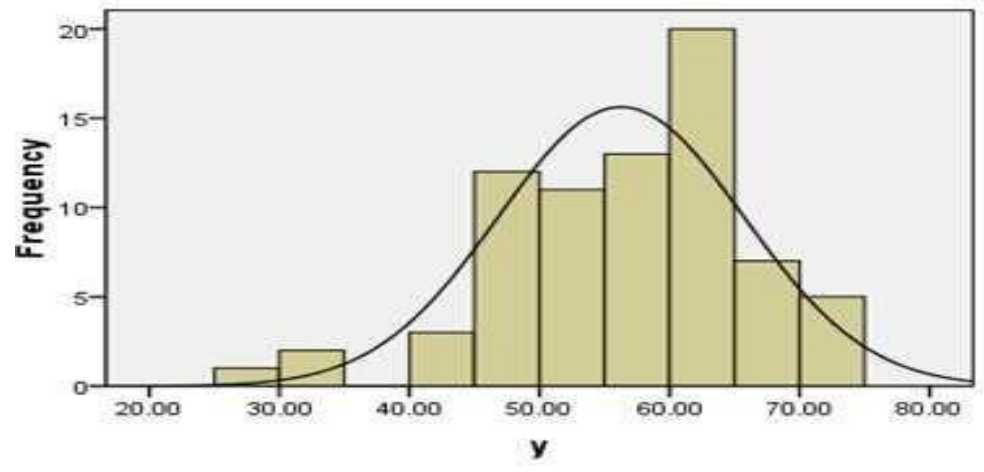

Mean $=56.27$
Std. Dev $=9.448$
$N=74$

Figure 7

EMPLOYEE PRODUCTIVITY VARIABLE HISTOGRAM GRAPH (Y) 


\section{First Hypothesis Test}

There is a disciplined influence on employee productivity. For each of the first hypothesis tests described as follows :

\section{Simple correlation coefficient:}

The coefficient of discipline correlation (X1) and employee productivity (Y) is 0.790 , meaning that the close relationship between discipline and employee productivity is $79 \%$. This relationship is strong because it is between $0.600-0.799$, which means that if discipline increases, employee productivity also increases or vice versa. While the coefficient of determination ( $\mathrm{r}) 2$ is calculated by using the following formula:

$$
\begin{aligned}
& r^{2} \times 100 \\
& =\% \\
& \mathrm{Kd}=\quad \begin{array}{l}
(0,790)^{2} \\
\times 100 \%
\end{array} \\
& =\quad(0,790)^{2} \\
& =\quad 62,4 \%
\end{aligned}
$$

The result of calculation obtained the coefficient of determination (r)2 is 0.624 which means employee productivity of $62.4 \%$ is determined by discipline and the rest is influenced by other factors of $37.6 \%$.

\section{Test Result t}

From the results of data processing with spss program, obtained $t$ value count as follows (Table 7):

\begin{tabular}{|c|c|c|c|}
\hline \multicolumn{3}{|c|}{ Table 7 } \\
\multicolumn{3}{|c|}{ FIRST HYPOTHESIS $\mathbf{t}_{\text {count }}$ AND } & \multicolumn{2}{|c|}{ table VALUES } \\
\multirow{2}{*}{ Equation } & Value & Value & \multirow{2}{*}{ Sig. } \\
\cline { 2 - 3 } & $\mathbf{t}_{\text {count }}$ & $\mathbf{T}_{\text {table }}$ & \\
\hline \multirow{2}{*}{ Discipline (X1) on Employee Productivity (Y) } & 10,940 & 2,000 & \multirow{2}{*}{0,000} \\
\hline
\end{tabular}

Based on table above, thitung value obtained by 10,940 , while $t_{\text {table }}$ in $\alpha(0.05)$ of 2,000 . Thus $t_{\text {count }}>t_{\text {table, }}$, so clearly Ho was rejected and Ha accepted. This indicates that discipline has a positive and significant effect on employee productivity.

\section{Test Result F}

From the results of computer processing based on SPSS calculation, obtained the value of $F_{\text {count }}$ coefficient as follows Table 8: 


\begin{tabular}{|c|c|c|c|}
\hline \multicolumn{4}{|c|}{$\begin{array}{c}\text { Table } 8 \\
\text { FIRST HYPOTHESIS VALUE } \text { F }_{\text {count }} \text { AND F table } \\
\end{array}$} \\
\hline Equation & $\begin{array}{l}\text { Value } \\
\mathrm{F}_{\text {count }}\end{array}$ & $\begin{array}{l}\text { Value } \\
\mathrm{F}_{\text {table }}\end{array}$ & Sig. \\
\hline Discipline (X1) on Employee Productivity (Y) & $1,19,676$ & 3,98 & 0,000 \\
\hline
\end{tabular}

From the table above it is known that the value of $F_{\text {count }}$ is 119.676. Simultaneously, the critical price of $F_{\text {table }}$ value with free degree numerator 1 and denominator $72 \alpha(0.05)$ is 3.98 . Thus $\mathrm{F}_{\text {count }}>\mathrm{F}_{\text {table, }}$, so clearly Ho was rejected, and Ha accepted. This indicates that discipline has a positive and significant effect on employee productivity.

\section{Simple Regression Equation}

From the spss calculation results, the following results are obtained:

$$
\begin{aligned}
& \hat{Y}=a+b_{1} X_{1} \\
& \hat{Y}=1,879+0,945 X_{1}
\end{aligned}
$$

This equation means that every 1 discipline variable score $\left(\mathrm{X}_{1}\right)$, affects the employee productivity variable $(\mathrm{Y})$ by 0.945 , assuming another variable is constant in value.

\section{Second Hypothesis Test}

Second Hypothesis: "There is an influence of the work environment on employee productivityll. For each second hypothesis test is described as follows :

\section{Simple Correlation Coefficient}

The coefficient value of the correlation of the work environment $\left(\mathrm{X}_{2}\right)$ with employee productivity (Y) is 0.776 , meaning that the relationship between the work environment and employee productivity is $77.6 \%$. This relationship is strong because it is between $0.600-0.799$, which means that if the work environment improves then employee productivity also increases or vice versa.

While the coefficient of determination $(r)^{2}$ is calculated by using the following formula:

$$
\begin{array}{rlr}
\mathrm{Kd} & & \mathrm{r}^{2} \times 100 \\
& & (0,776)^{2} \\
& & \times 100 \% \\
& =0,602 \times \\
& & 100 \% \\
& & 60,2 \%
\end{array}
$$

From the calculation obtained the coefficient of determination $(r)^{2}$ is 0.602 , which means employee productivity of $60.2 \%$ is determined by the work environment and the rest is influenced by other factors of $39.8 \%$. 


\section{Test Result t}

From the results of data processing with spss program, obtained t value count as follows (Table 9):

\begin{tabular}{|c|c|c|c|}
\hline \multicolumn{3}{|c|}{ Table 9 } & \multicolumn{2}{c|}{} \\
SECOND HYPOTHESIS tcount AND t table VALUES & \multicolumn{1}{|c|}{ Value } & Value & \multirow{2}{*}{ Sig. } \\
\cline { 2 - 3 } Equation & $\mathbf{t}_{\text {count }}$ & $\mathbf{T}_{\text {table }}$ & \\
\hline Discipline (X1) on Employee Productivity (Y) & 10,434 & 2,000 & 0,000 \\
\hline
\end{tabular}

Based on table above, $t_{\text {count }}$ value obtained by 10,434 , while $t_{\text {table }}$ in $\alpha(0.05)$ of 2,000 . Thus

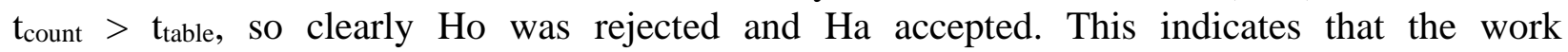
environment has a positive and significant effect on employee productivity

\section{Test Result F}

From the results of computer processing based on SPSS calculation, obtained the value of $\mathrm{F}_{\text {count }}$ coefficient as follows (Table 10):

\begin{tabular}{|c|c|c|c|}
\hline \multicolumn{3}{|c|}{ Table 10 } \\
\hline \multicolumn{2}{|c|}{ SECOND HYPOTHESIS VALUE F count AND F $_{\text {table }}$} \\
\hline Equation & Value $\mathrm{F}_{\text {count }}$ & Value $\mathrm{F}_{\text {table }}$ & Sig. \\
\hline Work Environment (X2) on Employee Productivity (Y) & $1,08,868$ & 3,98 & 0,000 \\
\hline
\end{tabular}

From the table above it is known that the value of Fcount is 108,868 . While the critical price of $F_{\text {table }}$ value with free degree numerator 1 and denominator $72 \alpha(0.05)$ is 3.98. Thus $F_{\text {count }}>$ $\mathrm{F}_{\text {table, }}$ so clearly Ho was rejected and $\mathrm{Ha}$ accepted. This indicates that the work environment has a positive and significant effect on employee productivity.

\section{Simple Regression Equation}

From the calculation results, the following results are obtained :

$$
\begin{aligned}
& \hat{Y}=a+b_{2} X_{2} \\
& \hat{Y}=10,260+0,804 X_{2}
\end{aligned}
$$

This equation means that every 1 work environment variable score $\left(\mathrm{X}_{2}\right)$, affects the employee productivity variable (Y) by 0.804 , assuming other variables have a constant value

\section{Third Hypothesis Test}

Third Hypothesis: "There is an influence of discipline and work environment together on employee productivity on. For each of the first hypothesis tests described as follows:

\section{Multiple Correlation Coefficients}


The coefficient value of multiple correlation discipline $\left(\mathrm{X}_{1}\right)$ and work environment $\left(\mathrm{X}_{2}\right)$ with employee productivity (Y) is 0.804 , which means the relationship of discipline variables $\left(\mathrm{X}_{1}\right)$ and work environment $\left(\mathrm{X}_{2}\right)$ with employee productivity bound variables $(\mathrm{Y})$ indicates a very strong relationship. While the amount of coefficient of determination or R Square is 0.646 which is the squealing of the correlation coefficient. This showed $64.6 \%$ of employee productivity variables were determined by variable factors of discipline and work environment, while the remaining $35.4 \%$ determined other factors, which in this study could not be researched.

\section{Test Result t}

From the results of data processing with spss program, obtained t value count as follows (Table 11):

\begin{tabular}{|l|c|c|c|}
\hline \multicolumn{3}{|c|}{ Table 11 } \\
\multicolumn{1}{|c|}{ THIRD HYPOTHESIS $\mathbf{t}_{\text {count }}$ AND } & \multicolumn{2}{|c|}{ table VALUES } \\
\multicolumn{1}{|c|}{ Equation } & Value & Value & \multirow{2}{*}{ Sig. } \\
\cline { 2 - 3 } & $\mathbf{t}_{\text {count }}$ & $\mathbf{T}_{\text {table }}$ & \\
\hline Discipline (X1) on Employee Productivity (Y) & 2,976 & 2,000 & 0,000 \\
\hline $\begin{array}{l}\text { Work Environment (X2) on Employee } \\
\text { Productivity (Y) }\end{array}$ & 2,087 & 2,000 & 0,000 \\
\hline
\end{tabular}

Based on the Table 11 above obtained the value of discipline variable $t_{\text {count }}$ of 2,976, while

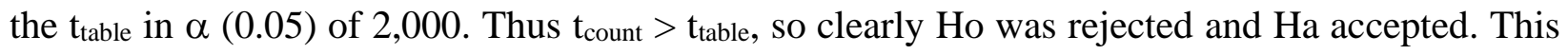
indicates that discipline has a positive and significant effect on employee productivity. While the $t_{\text {count }}$ value of the work environment variable is 2,087 , while the $\alpha(0.05)$ is 2,000 . Thus $t_{\text {count }}>$

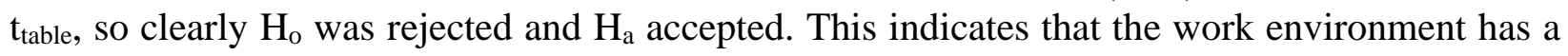
positive and significant effect on employee productivity.

\section{Test Result F}

From the results of computer processing based on statistical calculations, obtained the value of the $\mathrm{F}_{\text {count }}$ coefficient as follows (Table 12):

\begin{tabular}{|l|c|c|c|}
\hline \multicolumn{4}{|c|}{ Table 12 } \\
\multicolumn{1}{|c|}{ THIRD HYPOTHESIS VALUE F } \\
\multicolumn{1}{|c|}{ Equation } & $\begin{array}{c}\text { Value } \\
\mathrm{F}_{\text {count }}\end{array}$ & $\begin{array}{c}\text { Value } \\
\mathrm{F}_{\text {table }}\end{array}$ & Sig. \\
\hline $\begin{array}{l}\text { Discipline (X1) and Work Environment (X2) on } \\
\text { Employee Productivity (Y) }\end{array}$ & 64,805 & 3,13 & 0,000 \\
\hline
\end{tabular}

From the table above it is known that the value of $F_{\text {count }}$ is 64.805 . While the critical price of $F_{\text {table }}$ value with free degree numerator 2 and denominator $71 \alpha(0.05)$ of 3.13. Thus $F_{\text {count }}>$

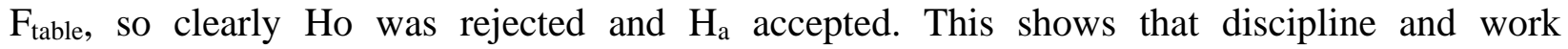
environment have a positive and significant effect on employee productivity

\section{Multiple Regression Equations}

From the results of statistical calculations, the following results are obtained: 


$$
\begin{aligned}
& \hat{Y}=a+b_{1} X_{1}+b_{2} X_{2} \\
& \hat{Y}=2,800+0,579 X_{1}+0,352 X_{2}
\end{aligned}
$$

This equation means that:

1) Each 1 discipline variable score $\left(\mathrm{X}_{1}\right)$ affects the employee productivity variable $(\mathrm{Y})$ of 0.579 , assuming the work environment variable $\left(\mathrm{X}_{2}\right)$ is of constant value.

2) Every 1 work environment variable score $\left(\mathrm{X}_{2}\right)$ affects the employee productivity variable $(\mathrm{Y})$ of 0.352 , assuming the discipline variable $\left(\mathrm{X}_{1}\right)$ value is constant. significant.

Based on the test results of the three hypotheses above, it turns out that all hypotheses are acceptable and

\section{DISCUSSION}

\section{The Influence of Discipline on Employee Productivity}

The results of the correlation analysis showed that the relationship between discipline variables and employee productivity was 0.790 . While the coefficient of determination is 0.624 . This means that $62.4 \%$ of variations occurring in employee productivity variables (Y) can be predicted by discipline variables (X1) or in other words discipline variables as predictable predicate variables to predict employee productivity variables in state-owned public agency companies by $62.4 \%$.

From the calculation of statistical programs obtained a calculated t value of 10,940, while it is known that the critical point of acceptance in table $t$ is 2,000 . Thus the $t_{\text {count }}>t_{\text {table, }}$, so clearly Ho was rejected, and $\mathrm{Ha}$ accepted. This indicates that discipline has a positive and significant effect on employee productivity in publicly owned companies.

\section{The Effect of the Work Environment on Employee Productivity}

The results of correlation analysis showed that the relationship between work environment variables and employee productivity was 0.776 . While the coefficient of determination is 0.602 . This means that $60.2 \%$ of variations occurring in employee productivity variables (Y) can be predicted by work environment variables (X2) or work environment variables as predictable predicate variables to predict employee productivity variables in state-owned public agency companies by $60.2 \%$.

From the calculation results with the statistics program obtained t-count value of 10,434 , while it is known that the critical point of acceptance in table $t$ is 2,000. Thus the $t$-count is $>\mathrm{t}$ table, so it is clear Ho was rejected, and Ha accepted. This indicates that the work environment has a positive and significant effect on employee productivity in publicly owned companies.

\section{The Influence of Discipline and Work Environment together on employeeProductivity}

The result obtained the value of the coefficient of multiple correlations (R) of 0.804 . The figure indicates that there is a relationship between the two free variables and bound variables. The coefficient of multiple determination $\left(\mathrm{R}^{2}\right)$ of discipline variables and work environment against employee productivity is 0.646 . The value informs that $64.6 \%$ of variations occurring in employee productivity variables can be predicted by the two free variables together. 
From the calculation results obtained $F_{\text {count }}$ value of 64,805 . While the critical price of $F_{\text {table }}$

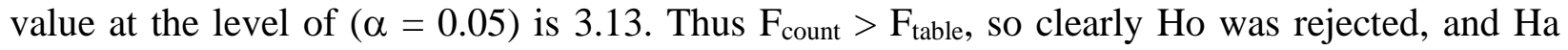
accepted. This shows that jointly discipline and work environment has a positive and significant effect on employee productivity in state-owned public bodies

\section{CONCLUSION}

There is a positive influence between discipline and employee productivity. From the hypothetical test results obtained $t_{\text {count }}$ value of 10,940 , while obtained $t_{\text {table }}$ of 2,000 . Thus $t_{\text {count }}>$

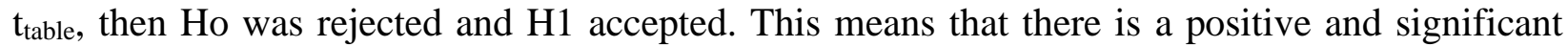
influence of discipline on employee productivity. There is a positive influence between the work environment and employee productivity. From the results of hypothesis testing obtained thitung value of 10,434 , while obtained $t_{\text {table }}$ of 2,000 . Thus $t_{\text {count }}>t_{\text {table, }}$, then Ho was rejected, and $\mathrm{H} 1$ accepted. This means that there is a positive and significant impact of the work environment on employee productivity. From the Anova test, it was obtained that $F_{\text {count }}(64,805)$ is greater than $F_{\text {table }}(3.13)$, it can be said that discipline variables and work environment together can be used to stimulate employee productivity variables.

\section{REFERENCE}

Abdullah, R., Sabar, R., \& Mustafar, M. (2018). Green Halal supply chain in Malaysian halal food companies: A conceptual framework. International Journal of Supply Chain Management, 7(5), 502-510. https://www.scopus.com/inward/record.uri?eid=2-s2.085060870564\&partnerID=40\&md5=04ca49f07d21949606b68e3ce6c0a3c1

Abell, T.N., \& Sevian, H. (2020). Analyzing Chemistry Teachers' Formative Assessment Practices Using Formative Assessment Portfolio Chapters. Journal of Chemical Education, 97(12), 4255-4267. https://doi.org/10.1021/acs.jchemed.0c00361

Abraham, A., \& Seyyed, F.J. (2012). Deepening the GCC debt markets: The Saudi Arabian experience. In The GCC Economies: Stepping up to Future Challenges. https://doi.org/10.1007/978-1-4614-1611-1_2

Achu Ayuk, A., Chimaobi, O., Omang, T.A., \& Emeka Nwankwo, E. (2020). Continuous ex-offenders' reformation and avoidance of recidivistic acts in Nigeria. International Journal of Criminology and Sociology, 9, 18311837. https://doi.org/10.6000/1929-4409.2020.09.187

Afanasyev, V.Y., Ukolov, V.F., Bolshakova, O.I., Baykova, O.V, Kislenko, N.A., \& Alekseev, A.O. (2020). Adaptive impact factor research concerning effectiveness of the introduction and use of digital twins for oil and gas deposits. International Journal of Criminology and Sociology, 9, 2043-2047. https://doi.org/10.6000/1929-4409.2020.09.239

Ahmad, A., \& Chowdhury, D. (2020). An investigation into the management of change in private sector healthcare organizations in bangladesh: A mixed-method inquiry based on the implementation of a new framework to support healthcare organizations. Review of Applied Socio-Economic Research, 20(2), 5-16. https://www.scopus.com/inward/record.uri?eid=2-s2.085099256053\&partnerID=40\&md5=53682dbaef9aad669a95da24e8f9c428

Ahn, J.Y., \& Huang, S. (2020). Types of employee training, organizational identification, and turnover intention: Evidence from Korean employees. Problems and Perspectives in Management, 18(4), 517-526. https://doi.org/10.21511/ppm.18(4).2020.41

Alhamda, S., Barlian, E., Razak, A., Riyadi, B.S., Herawati, N., \& Anggara, A.T. (2020). Deviation of management of medical waste from hospital implication upon environmental damage in west sumatera, Indonesia. International Journal of Criminology and Sociology, 9, 1773-1781. https://doi.org/10.6000/19294409.2020.09.203

Alluhidan, M., Tashkandi, N., Alblowi, F., Omer, T., Alghaith, T., Alghodaier, H., Alazemi, N., Tulenko, K., Herbst, C.H., Hamza, M.M., \& Alghamdi, M.G. (2020). Challenges and policy opportunities in nursing in Saudi Arabia. Human Resources for Health, 18(1). https://doi.org/10.1186/s12960-020-00535-2

Alsaghir, L., Abdallah, N., \& Bazan, S.B. (2020). Optimizing recruitment online: The critical importance of using 
the right channels. International Journal of E-Business Research, 16(4), 18-33. https://doi.org/10.4018/IJEBR.2020100102

Alter, KJ., Clipperton, J., Schraudenbach, E., \& Rozier, L. (2020). Gender and Status in American Political Science: Who Determines Whether a Scholar Is Noteworthy? Perspectives on Politics, 18(4), 1048-1067. https://doi.org/10.1017/S1537592719004985

Alzamel, S., Nazri, M., \& Omar, S. (2020). Factors influencing e-entrepreneurial intention among female students in Saudi Arabia. International Journal of Criminology and Sociology, 9, 1996-2003. https://doi.org/10.6000/1929-4409.2020.09.234

Anguelov, K., Stoyanova, T., \& Tamošiūnienè, R. (2020). Research of motivation of employees in the it sector in Bulgaria. Entrepreneurship and Sustainability Issues, 7(3), 2556-2567. https://doi.org/10.9770/jesi.2020.7.3(73)

Apaolaza, U., Lizarralde, A., \& Oyarbide-zubillaga, A. (2020). Modern project management approaches in uncertainty environments: A comparative study based on action research. Sustainability (Switzerland), 12(24), 1-17. https://doi.org/10.3390/su122410542

Baradaran, V., \& Hosseinian, A.H. (2020). A bi-objective model for redundancy allocation problem in designing server farms: mathematical formulation and solution approaches. International Journal of Systems Assurance Engineering and Management, 11(5), 935-952. https://doi.org/10.1007/s13198-020-01020-8

Bhatt, A., \& Bahuguna, R. (2019). Women prisoners and human rights: The juxtaposition of rights and reality. International Journal on Emerging Technologies, $10(1), \quad 163-170$. https://www.scopus.com/inward/record.uri?eid=2-s2.085074629281\&partnerID=40\&md5=282b84c67333e222dc911d791c1a47a9

Bianchi, M., Valle, I.D., \& Tapia, C. (2020). Measuring eco-efficiency in European regions: Evidence from a territorial perspective. Journal of Cleaner Production, 276. https://doi.org/10.1016/j.jclepro.2020.123246

Björkhagen Turesson, A. (2020). Conceptions, Norms, and Values in the Work of Child Protective Services with Families at Risk: An Analysis of Social Workers' Diaries. Clinical Social Work Journal, 48(4), 369-379. https://doi.org/10.1007/s10615-019-00720-4

Bove, J. (2020). Neues Sehen fur den Vierjahresplan: Zur Vermittlung von Fotobestanden aus der NS-Zeit am Beispiel des Nachlasses Karl Theodor Gremmler. Zeitschrift Fur Bibliothekswesen Und Bibliographie, 67(56), 317-335. https://doi.org/10.3196/1864295020675656

Brombin, V., Mistri, E., Feudis, M.D., Forti, C., Salani, G.M., Natali, C., Falsone, G., Antisari, L.V, \& Bianchini, G. (2020). Soil carbon investigation in three pedoclimatic and agronomic settings of northern Italy. Sustainability (Switzerland), 12(24), 1-19. https://doi.org/10.3390/su122410539

Brown, M.E., Backer, D., Billing, T., White, P., Grace, K., Doocy, S., \& Huth, P. (2020). Empirical studies of factors associated with child malnutrition: highlighting the evidence about climate and conflict shocks. Food Security, 12(6), 1241-1252. https://doi.org/10.1007/s12571-020-01041-y

Busta, L., \& Russo, S.E. (2020). Enhancing Interdisciplinary and Systems Thinking with an Integrative Plant Chemistry Module Applied in Diverse Undergraduate Course Settings. Journal of Chemical Education, 97(12), 4406-4413. https://doi.org/10.1021/acs.jchemed.0c00395

Canel, M.J., Oliveira, E.S., \& Luoma-aho, V. (2017). Exploring citizens' judgments about the legitimacy of public policies on refugees: In search of clues for governments' communication and public diplomacy strategies. Journal of Communication Management, 21(4), 355-369. https://doi.org/10.1108/JCOM-02-2017-0025

Cassely, L., Revelli, C., Ben Larbi, S., \& Lacroux, A. (2020). Sustainable development drivers of companies: An international and multilevel analysis. Corporate Social Responsibility and Environmental Management, 27(5), 2028-2043. https://doi.org/10.1002/csr.1944

Chalikias, M., Raftopoulou, I., Sidiropoulos, G., Kyriakopoulos, G.L., \& Zakopoulos, V. (2020). -The school principal's role as a leader in teachers" " professional development: The case of public secondary education in Athensll.l Problems and Perspectives in Management, 18(4). https://doi.org/10.21511/ppm.18(4).2020.37

Charity Hudley, A.H., Mallinson, C., \& Bucholtz, M. (2020). Toward racial justice in linguistics: Interdisciplinary insights into theorizing race in the discipline and diversifying the profession. Language, 96(4), e200-e235. https://doi.org/10.1353/lan.2020.0074

Chen, Y., Daamen, T.A., Heurkens, E.W.T.M., \& Verheul, W.J. (2020). Interdisciplinary and experiential learning in urban development management education. International Journal of Technology and Design Education, 30(5), 919-936. https://doi.org/10.1007/s10798-019-09541-5

Choudhury, T.T., Paul, S.K., Rahman, H.F., Jia, Z., \& Shukla, N. (2020). A systematic literature review on the service supply chain: research agenda and future research directions. Production Planning and Control, 31(16), 1363-1384. https://doi.org/10.1080/09537287.2019.1709132 
Collier-Bordet, C., Viguier, K., Reverchon, C., \& Rossello, J.J. (2020). Politics of the inclusive school: Experience of a ditep teaching unit outsourced in a local school [Politique de l'école inclusive: Expérience d'une unité d'enseignement de ditep externalisée dans une école de quartier]. Enfances et Psy, 87(3), 159-168. https://doi.org/10.3917/ep.087.0159

Condé, G.C.P., \& Martens, M.L. (2020). Six sigma project generation and selection: literature review and feature based method proposition. Production Planning and Control, 31(16), 1303-1312. https://doi.org/10.1080/09537287.2019.1706196

Cooke, F.L., Schuler, R., \& Varma, A. (2020). Human resource management research and practice in Asia: Past, present and future. Human Resource Management Review, 30(4). https://doi.org/10.1016/j.hrmr.2020.100778

Cooper, A., MacGregor, S., \& Shewchuk, S. (2020). A research model to study research-practice partnerships in education. Journal of Professional Capital and Community, 6(1), 44-63. https://doi.org/10.1108/JPCC-112019-0031

Cruz, L., Barata, E., \& Ferreira, J.P. (2012). Performance in urban public transport systems: A critical analysis of the Portuguese case. International Journal of Productivity and Performance Management, 61(7), 730-751. https://doi.org/10.1108/17410401211263836

Cubero, M., Cubero-Pérez, R., \& Bascón, M.J. (2020). -My tutor doesn't say thatl: The legitimized voices in dialogic reflection on teaching practices. Dialogic Pedagogy, 8, SA26-SA44. https://doi.org/10.5195/DPJ.2020.311

Cury, P.H.A., \& Saraiva, J. (2018). Time and motion study applied to a production line of organic lenses in manaus industrial hub. Gestao e Producao, 25(4), 901-915. https://doi.org/10.1590/0104-530X2881-18

D‘Intino, J., Buccolini, M., Di Nardo, E., Esposito, G., \& Miccadei, E. (2020). Geomorphology of the Anversa degli Abruzzi badlands area (Central Apennines, Italy). Journal of Maps, 16(2), 488-499. https://doi.org/10.1080/17445647.2020.1780169

da Costa, J.M.H., Amaral, C.S.T., Fernandes, S.C., \& Rozenfeld, H. (2019). A new way to diagnose the new product development process based on recurring current reality trees. Business Process Management Journal, 25(4), 667-687. https://doi.org/10.1108/BPMJ-01-2017-0020

Daanaa, H.-S.A., Abdou, M., Goda, H.A., Abbas, M.T., Hamza, M.A., Sarhan, M.S., Youssef, H.H., Hamed, R., ElTahan, M., Fayez, M., Ruppel, S., \& Hegazi, N.A. (2020). Plant pellets: A compatible vegan feedstock for preparation of plant-based culture media and production of value-added biomass of rhizobia. Sustainability (Switzerland), 12(20), 1-19. https://doi.org/10.3390/su12208389

Dal, V., Akçagün, E., \& Yilmaz, A. (2013). Using lean manufacturing techniques to improve production efficiency in the ready wear industry and a case study. Fibres and Textiles in Eastern Europe, 100(4), 16-22. https://www.scopus.com/inward/record.uri?eid=2-s2.084879526047\&partnerID=40\&md5=fbf0d90ee3db2dda0f414e301a0c8f77

Dangelico, R.M. (2016). Green Product Innovation: Where we are and Where we are Going. Business Strategy and the Environment, 25(8), 560-576. https://doi.org/10.1002/bse.1886

Dartey-Baah, K., Quartey, S.H., \& Osafo, G.A. (2020). Examining occupational stress, job satisfaction and gender difference among bank tellers: evidence from Ghana. International Journal of Productivity and Performance Management, 69(7), 1437-1454. https://doi.org/10.1108/IJPPM-07-2019-0323

Dawit, M., Dinka, M.O., \& Leta, O.T. (2020). Implications of adopting drip irrigation system on crop yield and gender-sensitive issues: The case of Haramaya district, Ethiopia. Journal of Open Innovation: Technology, Market, and Complexity, 6(4), 1-17. https://doi.org/10.3390/joitmc6040096

Deane, P. (2020). Building and Justifying Interpretations of Texts: A Key Practice in the English Language Arts. ETS Research Report Series, 2020(1), 1-53. https://doi.org/10.1002/ets2.12304

Degtyarev, S.I., Zavhorodnia, V.M., \& Polyakova, L.G. (2020). Transformations in the Field of public education of the Ukrainian State in 1918. Part 1. European Journal of Contemporary Education, 9(4), 971-983. https://doi.org/10.13187/ejced.2020.4.971

ĐorĎević, K.N. (2020). Development of ethnolinguistics in Slovakia [Razvoj etnolingvistike u slovaČkoj]. Komunikacija i Kultura Online, 11(11), 70-82. https://doi.org/10.18485/kkonline.2020.11.11.4

Dwiartama, A. (2018). From disciplinary societies' to _societies of control': An historical narrative of agrienvironmental governance in Indonesia. In Agri-Environmental Governance as an Assemblage: Multiplicity, Power, and Transformation. https://doi.org/10.4324/9781315114941

Ellison, D. (2013). How to obtain and maintain a goal of zero accidents. Web Coating and Handling Conference 2013, $\quad 1, \quad 330-343 . \quad$ https://www.scopus.com/inward/record.uri?eid=2-s2.084901370136\&partnerID=40\&md5=7749a8ee2089d4b00fe43f6731c84538

Engelbrecht, L.K. (2009). An approach to financial vulnerability reduction: Financial literacy education within a 
social development paradigm ['n Benadering tot finansiële kwesbaarheidsreduksie: Finansiële geletterdheidsopvoeding binne 'n maatskaplike ontwikkelingsparadigma]. Tydskrif Vir Geesteswetenskappe, 49(2), 201-218. https://www.scopus.com/inward/record.uri?eid=2-s2.068949131200\&partnerID=40\&md5=53295404285ce996b4e0cc03c00ee242

Erna, H. (2020). Business Strategy, Corporate Governance and Sustainability Reporting:An Analysis of the Fit Contingency Approach. Journal of Asian Finance, Economics and Business, 7(12), 761-771. https://doi.org/10.13106/JAFEB.2020.VOL7.NO12.761

Fanego, T. (2020). On the History of the English Progressive Construction Jane came whistling down the street. Journal of English Linguistics, 48(4), 319-354. https://doi.org/10.1177/0075424220945008

Farley-Ripple, E.N., Oliver, K., \& Boaz, A. (2020). Mapping the community: use of research evidence in policy and practice. Humanities and Social Sciences Communications, 7(1). https://doi.org/10.1057/s41599-020-00571-2

Fischer, J.E., Genser, B., Nauroth, P., Litaker, D., \& Mauss, D. (2020). Estimating the potential reduction in future sickness absence from optimizing group-level psychosocial work characteristics: a prospective, multicenter cohort study in German industrial settings. Journal of Occupational Medicine and Toxicology, 15(1). https://doi.org/10.1186/s12995-020-00284-x

Fitzgerald, S.R., \& Jiang, Z. (2020). Scholarly Publishing at a Crossroads: Scholarly Perspectives on Open Access. Innovative Higher Education, 45(6), 457-469. https://doi.org/10.1007/s10755-020-09508-8

Forte, W., Tucker, J., Matonti, G., \& Nicolò, G. (2017). Measuring the intellectual capital of Italian listed companies. Journal of Intellectual Capital, 18(4), 710-732. https://doi.org/10.1108/JIC-08-2016-0083

Gadomska-Lila, K. (2020). Effectiveness of reverse mentoring in creating intergenerational relationships. Journal of Organizational Change Management, 33(7), 1313-1328. https://doi.org/10.1108/JOCM-10-2019-0326

Gaillard, A., Sultan-Taïeb, H., Sylvain, C., \& Durand, M.-J. (2020). Economic evaluations of mental health interventions: A systematic review of interventions with work-focused components. Safety Science, 132. https://doi.org/10.1016/j.ssci.2020.104982

Ghosh, S., \& Seethamraju, S. (2020). Reactive Distillation for Methanol Synthesis: Parametric Studies and Optimization Using a Non-polar Solvent. Process Integration and Optimization for Sustainability, 4(4), 325342. https://doi.org/10.1007/s41660-020-00122-x

Giacalone, M., Nissi, E., \& Cusatelli, C. (2020). Dynamic efficiency evaluation of Italian judicial system using DEA based Malmquist productivity indexes. Socio-Economic Planning Sciences, 72. https://doi.org/10.1016/j.seps.2020.100952

Gu, W., Hou, F., \& Picot, G. (2020). Immigration and firm productivity: evidence from the Canadian EmployerEmployee Dynamics Database. Journal of Productivity Analysis, 54(2-3), 121-137. https://doi.org/10.1007/s11123-020-00588-4

Guan, N.H., Bunyamin, M.A.H., \& Khamis, N. (2020). Perspectives of STEM education from physics teachers“ points of view: A quantitative study. Universal Journal of Educational Research, 8(11 C), 72-82. https://doi.org/10.13189/ujer.2020.082309

Gubarenko, I.V, Kovalenko, V.I., Kovalenko, E.V, Miyusov, V.A., \& Sokolova, O.A. (2020). Methods of social interaction learning for students of non-profit organizations. International Journal of Criminology and Sociology, 9, 1898-1905. https://doi.org/10.6000/1929-4409.2020.09.220

Gulzar, S., Ghauri, S., Abbas, Z., Hussain, K., \& Jibril, A.B. (2020). -Antecedents of employee wellbeing in the banking sector: The moderating role of working environment.ll Problems and Perspectives in Management, 18(4), 448-460. https://doi.org/10.21511/ppm.18(4).2020.36

Guo, C.-J. (2010). Theoretical perspectives of science teacher education. Asia-Pacific Forum on Science Learning and Teaching, 11(1), 1-3. https://www.scopus.com/inward/record.uri?eid=2-s2.078649802787\&partnerID=40\&md5=893f3fcbba784c314d2949388225aec4

Haghani, M., \& Bliemer, M.C.J. (2020). Covid-19 pandemic and the unprecedented mobilisation of scholarly efforts prompted by a health crisis: Scientometric comparisons across SARS, MERS and 2019-nCoV literature. Scientometrics, 125(3), 2695-2726. https://doi.org/10.1007/s11192-020-03706-z

Halliru, A.M., Loganathan, N., Golam Hassan, A.A., Mardani, A., \& Kamyab, H. (2020). Re-examining the environmental kuznets curve hypothesis in the economic community of West African states: A panel quantile regression approach. Journal of Cleaner Production, 276. https://doi.org/10.1016/j.jclepro.2020.124247

Harini, S., Maulana, L.H., Sudarijati, \& Juniarti, D. (2020). Performance, job stress and human capital motivation: A study on employee perspective. International Journal of Scientific and Technology Research, 9(4), 22952300 . https://www.scopus.com/inward/record.uri?eid=2-s2.085083861225\&partnerID=40\&md5=f620cb161add2cc0234297808f552fbc

Harris, J.G., Craig, E., \& Light, D.A. (2011). Talent and analytics: new approaches, higher ROI. Journal of Business 
Strategy, 32(6), 4-13. https://doi.org/10.1108/02756661111180087

Haynes, B., Brimacombe, K., Hare, C., \& Faupel-Badger, J. (2020). The national center for advancing translational sciences" intramural training program and fellow career outcomes. CBE Life Sciences Education, 19(4), 1-12. https://doi.org/10.1187/cbe.20-03-0048

Hill, P., \& Schmutz, A. (2020). Remote: Office Not Required-A Book Review. Journal of Extension, 58(6), 1-3. https://www.scopus.com/inward/record.uri?eid=2-s2.085098889456\&partnerID $=40 \& m d 5=b 88 f b 11$ be $1593 c 5 f 25 a 5 b 981 a 6 e 88 c 7 b$

Hong, J., \& Basturkmen, H. (2020). Incidental attention to academic language during content teaching in two EMI classes in South Korean high schools. Journal of English for Academic Purposes, 48. https://doi.org/10.1016/j.jeap.2020.100921

Horvat, G. (2009). Improvement of forestry office business operation by developing basic managing functions [Unaprecross d signenje poslovanja šumarije razvojem osnovnih funkcija upravljanja]. Sumarski List, 133(12), 39-51. $\quad$ https://www.scopus.com/inward/record.uri?eid=2-s2.065349177043\&partnerID=40\&md5=87de97d6070b476302f5abefa4e2567f

Hu, Y., \& Liu, L. (2020). Becoming industrious female citizens: Work, discipline, and negotiation in Chinese female prison. International Journal of Law, Crime and Justice, 63. https://doi.org/10.1016/j.ijlcj.2020.100420

Husin, W.N.W., \& Kernain, N.F.Z. (2020). The Influence of Individual Behaviour and Organizational Commitment Towards the Enhancement of Islamic Work Ethics at Royal Malaysian Air Force. Journal of Business Ethics, 166(3), 523-533. https://doi.org/10.1007/s10551-019-04118-7

Idoko, E.C., Nebo, G.N., \& Ukenna, S.I. (2020). Determinants of field salespersons" sales performance in deposit money banks: Does organizational commitment mediate? Banks and Bank Systems, 15(4), 204-220. https://doi.org/10.21511/bbs.15(4).2020.17

Ingsih, K., Astuti, S.D., \& Asri, D.I.P. (2017). Compensation as the most important factor in improving employee's Performance. International Journal of Economic Research, 14(6), 105-120. https://www.scopus.com/inward/record.uri?eid=2-s2.0-

85019572736\&partnerID $=40 \& \mathrm{md} 5=10 \mathrm{e} 9 \mathrm{eeff} 3 \mathrm{f0e} 70 \mathrm{fec} 105606 \mathrm{c} 7 \mathrm{c} 598 \mathrm{c} 9 \mathrm{c}$

ISBARY, G. (1962). TOPIC I: PROBLEME DER ENTWICKLUNGS-PLANUNG IN VERDICHTUNGSZONEN. Sociologia Ruralis, 2(1-2), 49-78. https://doi.org/10.1111/j.1467-9523.1962.tb00382.x

Jang, Y., Song, K., Park, M., \& Ahn, Y. (2020). Classifying the Business Model Types of International Construction Contractors. Journal of Construction Engineering and Management, 146(6). https://doi.org/10.1061/(ASCE)CO.1943-7862.0001836

Järvenpää, M. (2007). Making business partners: A case study on how management accounting culture was changed. European Accounting Review, 16(1), 99-142. https://doi.org/10.1080/09638180701265903

Ji, Y.G., Tao, W., \& Rim, H. (2020). Mapping corporate social responsibility research in communication: A network and bibliometric analysis. Public Relations Review, 46(5). https://doi.org/10.1016/j.pubrev.2020.101963

Jilcha Sileyew, K. (2020). Systematic industrial OSH advancement factors identification for manufacturing industries: A case of Ethiopia. Safety Science, 132. https://doi.org/10.1016/j.ssci.2020.104989

Johnston, M.R. (2020). Chemistry of Cannabis: An Interdisciplinary Course. Journal of Chemical Education, 97(12), 4311-4315. https://doi.org/10.1021/acs.jchemed.0c00930

Jones, A., Howe, A., Tilse, C., Bartlett, H., \& Stimson, B. (2010). Service integrated housing for Australians in later life. AHURI Final Report, 141, 1-169. https://www.scopus.com/inward/record.uri?eid=2-s2.084908072525\&partnerID=40\&md5=f32b726153e5e1d3da0658637bcfc577

Juanamasta, I.G., Wati, N.M.N., Hendrawati, E., Wahyuni, W., Pramudianti, M., Wisnujati, N. S., Setiawati, A. P., Susetyorini, S., Elan, U., Rusdiyanto, R., Astanto, D., Ulum, B., Khadijah, S.N., Trimarjono, A., Syafii, M., Mubarroq, A., Kristiningsih, K., Pratiwi, R.D., Veri, V., ... Umanailo, M.C.B. (2019). The role of customer service through customer relationship management $(\mathrm{Crm})$ to increase customer loyalty and good image. International Journal of Scientific and Technology Research, 8(10), 2004-2007.

Kanitvittaya, S., Suksai, U., Suksripanich, O., \& Pobkeeree, V. (2010). Laboratory quality improvement in Thailand's northernmost provinces. International Journal of Health Care Quality Assurance, 23(1), 22-34. https://doi.org/10.1108/09526861011010659

Karimi, H., \& Taghaddos, H. (2020). Impact of Age on the Strength of Experience and Education Role in Fatal Injuries Prevention in Iranian Construction Craft Workers. Journal of Construction Engineering and Management, 146(7). https://doi.org/10.1061/(ASCE)CO.1943-7862.0001857

Klimoviene, G., Barzdžiukiene, R., \& Račkauskaite, N. (2016). Developing students' communicative competence in Business English. Studies About Languages, 28, 102-113. https://doi.org/10.5755/j01.sal.0.28.14265 
Kögel, J., \& Wolbring, G. (2020). What It Takes to Be a Pioneer: Ability Expectations From Brain-Computer Interface Users. NanoEthics, 14(3), 227-239. https://doi.org/10.1007/s11569-020-00378-0

Kozorez, D.A., Dolgova, E.A., Korneenkova, A.V, Rumakina, A.V, \& Sha, M. (2020). Higher education institutions educational process digitalization in the context of the necessity to provide a model for students" choice of training areas and academic specialties. International Journal of Criminology and Sociology, 9, 3033-3039. https://doi.org/10.6000/1929-4409.2020.09.369

Kulikova, L., Aminova, D., \& Lyzhova, A. (2020). Use of economic and mathematical modeling tools in planning investments in fixed assets. International Journal of Criminology and Sociology, 9, 2510-2513. https://doi.org/10.6000/1929-4409.2020.09.305

Lackie, K., \& Tomblin Murphy, G. (2020). The impact of interprofessional collaboration on productivity: Important considerations in health human resources planning. Journal of Interprofessional Education and Practice, 21. https://doi.org/10.1016/j.xjep.2020.100375

Liao, J., Xue, H., \& Chen, J. (2020). Monitoring lake level changes on the Tibetan Plateau from 2000 to 2018 using satellite altimetry data [卫星测高数据监测青藏高原湖泊2010年-2018年水位变化]. Yaogan Xuebao/Journal of Remote Sensing, 24(12), 1534-1547. https://doi.org/10.11834/jrs.20209281

Lin, Y., Ma, S., \& Zhou, L. (2012). Manufacturing strategies for time based competitive advantages. Industrial Management and Data Systems, 112(5), 729-747. https://doi.org/10.1108/02635571211232299

Liogier, R. (2020). Identités globales et religion à 1‘ère digitale : vers les Global Identity Studies. Social Compass, 67(4), 553-575. https://doi.org/10.1177/0037768620953508

Longo, F. (2007). Implementing managerial innovations in primary care: Can we rank change drivers in complex adaptive organizations? Health Care Management Review, 32(3), $213-225$. https://doi.org/10.1097/01.HMR.0000281620.13116.ce

Lorenzo, D.K. (2001). A manager's guide to reducing human errors: Improving human performance in the process industries. API Publications, 770, X-46. https://www.scopus.com/inward/record.uri?eid=2-s2.027644539898\&partnerID=40\&md5=f656dfa77333363670086bbb30eb021d

Lund, K., Jeong, H., Grauwin, S., \& Jensen, P. (2020). Research in Education Draws Widely From the Social Sciences and Humanities. Frontiers in Education, 5. https://doi.org/10.3389/feduc.2020.544194

Mackert, M., Table, B., Yang, J., Bouchacourt, L., Woods, J.M., Bernhardt, J.M., \& Wagner, J.H. (2020). Applying Best Practices from Health Communication to Support a University's Response to COVID-19. Health Communication, 35(14), 1750-1753. https://doi.org/10.1080/10410236.2020.1839204

Malakauskaite, A., \& Navickas, V. (2010). Relation between the level of clusterization and tourism sector competitiveness [Klasterizacijos lygio ir turizmo sektoriaus konkurencingumo sąryšis]. Engineering Economics, $\quad 1, \quad 60-67 . \quad \mathrm{https}: / / w w w . s c o p u s . c o m / i n w a r d / r e c o r d . u r i ? e i d=2-s 2.0-$ 77949336507\&partnerID=40\&md5=16a5e2bfcc6bb0660988958b06f9cd7b

Mamun, A.A., Khaled, A.A., Ali, S.M., \& Chowdhury, M.M. (2012). A heuristic approach for balancing mixedmodel assembly line of type i using genetic algorithm. International Journal of Production Research, 50(18), 5106-5116. https://doi.org/10.1080/00207543.2011.643830

Manohar, Y. (2013). Corporate social responsibility: Activities in and around Visakhapatnam city. DESIDOC Journal of Library and Information Technology, 33(1), 7-10. https://doi.org/10.14429/djlit.33.1.3722

Martdianty, F., Coetzer, A., \& Susomrith, P. (2020). Job embeddedness of manufacturing SME employees in Indonesia. Employee Relations, 42(1), 180-193. https://doi.org/10.1108/ER-01-2019-0087

Martimianakis, M.A., Mylopoulos, M., \& Woods, N.N. (2020). Developing experts in health professions education research: knowledge politics and adaptive expertise. Advances in Health Sciences Education, 25(5), 11271138. https://doi.org/10.1007/s10459-020-10014-x

Martino, E. (2020). The Bail-in Beyond Unpredictability: Creditors' Incentives and Market Discipline. European Business Organization Law Review, 21(4), 789-828. https://doi.org/10.1007/s40804-020-00188-7

Masik, G., \& Studzińska, D. (2018). Evolution of the smart city concept and of research into it [Ewolucja koncepcji i badania miasta inteligentnego]. Przeglad Geograficzny, 90(4), 557-571. https://doi.org/10.7163/PrzG.2018.4.2

Mateescu, R.M., Maftei, M., Verjel, A.M., \& Lange, S. (2017). The interrelation between risk management and the organizational context: Influence, support and barriers. Proceedings of the 29th International Business Information Management Association Conference - Education Excellence and Innovation Management through Vision 2020: From Regional Development Sustainability to Global Economic Growth, 3292-3308. https://www.scopus.com/inward/record.uri?eid=2-s2.085029749481\&partnerID=40\&md5=abaee5b217084f199a1a95203c606b4e

Meng, A., Borg, V., \& Clausen, T. (2019). Enhancing the social capital in industrial workplaces: Developing 
workplace interventions using intervention mapping. Evaluation and Program Planning, 72, 227-236. https://doi.org/10.1016/j.evalprogplan.2018.11.007

Mikalauskas, R., Edmundas, J., Valantine, I., Fominiene, V.B., \& Vojtovic, S. (2013). Factors affecting competitiveness of services provided by sports clubs: A case of Kaunas City sports clubs. Transformations in Business and Economics, 12(2 B), 406-420. https://www.scopus.com/inward/record.uri?eid=2-s2.084885968184\&partnerID=40\&md5=44335a372aad997892419a6d1e3aa71a

Millstein, L.S., Allen, J., Bellin, M.H., Eveland, S.R., Baek, D., Agarwal, A., Hill, T., Mutchie, H., \& Cagle, J.G. (2020). An interprofessional training to improve advance care planning skills among medicine, nursing, and social work students. Journal of Interprofessional Education and Practice, 21. https://doi.org/10.1016/j.xjep.2020.100382

Mita, A.F., Utama, S., Fitriany, F., \& Wulandari, E.R. (2018). The adoption of IFRS, comparability of financial statements and foreign investors' ownership. Asian Review of Accounting, 26(3), 391-411. https://doi.org/10.1108/ARA-04-2017-0064

Mphatheni, M.R., Nkosi, S.L., Tutu, O.J., \& Gopal, N. (2020). An analysis of criminology as a profession in the republic of south Africa. International Journal of Criminology and Sociology, 9, 1822-1828. https://doi.org/10.6000/1929-4409.2020.09.208

Muazzam, A., Anjum, A., \& Visvizi, A. (2020). Problem-focused coping strategies, workplace bullying, and sustainability of heis. Sustainability (Switzerland), 12(24), 1-13. https://doi.org/10.3390/su122410565

Muyombano, E., \& Espling, M. (2020). Land use consolidation in Rwanda: The experiences of small-scale farmers in Musanze District, Northern Province. Land Use Policy, 99. https://doi.org/10.1016/j.landusepol.2020.105060

Mylona, E., \& Mihail, D. (2020). Exploring Public Employees' Motivation to Learn and Develop in Turbulent Times. The Role of Perceived Support and Organizational Commitment. International Journal of Public Administration, 43(16), 1366-1375. https://doi.org/10.1080/01900692.2019.1669174

Narayana Swamy, B.K., \& Nagaraju, Y. (2016). Methodological issues in social science research for bioresource conservation and livelihood development under global climate change. Environmental Science and Engineering (Subseries: Environmental Science), 203019, 66-81. https://doi.org/10.1007/978-3-319-31014$5 \_5$

Nascimento, A., \& Lopes, H.F. (2020). How we have been productive when Coronavirus locked us out of University. Fennia, 198(1-2), 243-246. https://doi.org/10.11143/FENNIA.99190

Nguyen, P.T., Nguyen, M.K., \& Dang, H.T. (2019). The factors affecting technology transaction value in Vietnam: technology demand approach. International Journal of Productivity and Performance Management, 69(2), 344-360. https://doi.org/10.1108/IJPPM-07-2018-0278

Nikolou-Walker, E., \& Curley, H. (2012). An examination, evaluation and analysis of work-based learning leadership within a higher education setting. Higher Education, Skills and Work-Based Learning, 2(2), 186200. https://doi.org/10.1108/20423891211224810

No Title. (n.d.).

Oey, E., Wijaya, W.A., \& Hansopaheluwakan, S. (2020). Forecasting and aggregate planning application - A case study of a small enterprise in Indonesia. International Journal of Process Management and Benchmarking, 10(1), 1-21. https://doi.org/10.1504/IJPMB.2020.104229

Oluwatayo, A.A., \& Adetoro, O. (2020). Influence of Employee Attributes, Work Context and Human Resource Management Practices on Employee Job Engagement. Global Journal of Flexible Systems Management, 21(4), 295-308. https://doi.org/10.1007/s40171-020-00249-3

Othman, K., Ismail, S.N., Mohd Fuad, S.H., Md Hasim, M., Othman, F., Abdullah, M.R., Zaidi, N., Addenan, N.A., \& Nik Nazli, N.N.N. (2019). Service period as a moderator to the behaviour and work performance relationship in the organisation. Asian Academy of Management Journal, 24, 51-65. https://doi.org/10.21315/aamj2019 24.s2.4

Ou, J., Yang, S., Wu, Y.-J., An, C., \& Xia, J. (2018). Systematic clustering method to identify and characterise spatiotemporal congestion on freeway corridors. IET Intelligent Transport Systems, 12(8), 826-837. https://doi.org/10.1049/iet-its.2017.0355

Ouyang, Z., Deng, X., Sun, Z., Long, H., Zhang, L., Li, F., \& Jin, G. (2020). Regional agricultural research in contributing to national economic development [面向国民经济主战场的区域农业研究]. Dili Xuebao/Acta Geographica Sinica, 75(12), 2636-2654. https://doi.org/10.11821/dlxb202012007

Pamies-Bertrn, A., \& Yuan, W. (2020). The spatial conceptualization of time in Spanish and Chinese. Yearbook of Phraseology, 11(1), 107-138. https://doi.org/10.1515/phras-2020-0007

Peprah, A.A., Agyemang, C.B., \& Damoah, O.B.O. (2020). Flexible working schedules in SMEs: Evidence from a 
developing country. Business Strategy and Development, 3(4), 640-647. https://doi.org/10.1002/bsd2.128 Pérez, F.J.P., Santa Cruz, F.G., \& López-Guzmá, T. (2015). An approximation to the managerial skills. Perspective from the regional administration in the province of Cordoba (Spain) [Una aproximación a las habilidades directivas. Perspectiva desde la administración autonómica en la provincia de Córdoba (España)]. Revista de Estudios Regionales, 102, 65-89. https://www.scopus.com/inward/record.uri?eid=2-s2.084932115411\&partnerID=40\&md5=a6aa9a160bd563a2c84a9bb274e07fff

Pogodziński, P.M., Świątkowski, B., Piątkowska-Małecka, J., Miśkowicz, I., Skrzyński, G., Badura, M., \& Jurgielewicz, A. (2020). The early medieval settlement, economy, and exploitation of the natural environment in the Puck Land based on the example of research in Błądzikowo (site 7) [Wczesnośredniowieczne osadnictwo, gospodarka i eksploatacja środowiska przyrodniczego w rejonie Ziemi Puckiej na przykładzie badań w Błądzikowie (st. 7)]. Przeglad Archeologiczny, 68. https://doi.org/10.23858/PA68.2020.012

Prabowo, B., Rochmatulaili, E., Rusdiyanto, \& Sulistyowati, E. (2020). Corporate governance and its impact in company's stock price: case study [Gobernabilidad corporativa y su impacto en el precio de las acciones de las empresas: Estudio de caso]. Utopia y Praxis Latinoamericana, 25(Extra10), $187-196$. https://doi.org/10.5281/zenodo.4155459

Prasad, P., \& Sana, A. (2020). Employees of different levels of hierarchy and their role and contribution towards team effectiveness in a service sector organization. International Journal of Scientific and Technology Research, 9(2), 2736-2742. https://www.scopus.com/inward/record.uri?eid=2-s2.085079668946\&partnerID=40\&md5=90bd6db7162a7ff82a1d83b24324bb2a

Prasetyo, P.E., Setyadahrma, A., \& Kistanti, N.R. (2020). The role of social capital in new products development and business competitiveness enhancement. International Journal of Scientific and Technology Research, 9(3), 1838-1843. https://www.scopus.com/inward/record.uri?eid=2-s2.085082670179\&partnerID=40\&md5=33c6f6662c1c2ce1e5f43640469b8299

Prashar, A. (2019). THANKYOU: from waste to resource. Emerald Emerging Markets Case Studies, 9(1), 1-21. https://doi.org/10.1108/EEMCS-03-2018-0038

Purohit, N. (2018). Reward encourages beast...oops, best! Emerald Emerging Markets Case Studies, 8(4), 1-17. https://doi.org/10.1108/EEMCS-07-2017-0188

Rameshwar, R., Saha, R., \& Sanyal, S.N. (2020). Strategic corporate social responsibility, capabilities, and opportunities: Empirical substantiation and futuristic implications. Corporate Social Responsibility and Environmental Management, 27(6), 2816-2830. https://doi.org/10.1002/csr.2005

Reiner, G., Cumyn, M., Hudon, M., \& Mas, S. (2019). Designing a database to assist legal thinking: A new approach to indexing using facets. Jusletter IT, February. https://www.scopus.com/inward/record.uri?eid=2$\mathrm{s} 2.0-85074240847 \&$ partnerID $=40 \& \mathrm{md} 5=8389 \mathrm{f} 5 \mathrm{fd} 7256 \mathrm{be} 8216 \mathrm{~b} 59 \mathrm{ad} 3657 \mathrm{~b} 25 \mathrm{~d} 0$

Revillot-Narváez, D., Pérez-Galarce, F., \& Álvarez-Miranda, E. (2020). Optimising the storage assignment and order-picking for the compact drive-in storage system. International Journal of Production Research, 58(22), 6949-6969. https://doi.org/10.1080/00207543.2019.1687951

Revin, I., Susimenko, E., Revina, E., \& Garaeva, M. (2020). Development of personal and professional culture as the basis for engineer's effective activities. International Journal of Criminology and Sociology, 9, 19391947. https://doi.org/10.6000/1929-4409.2020.09.227

Reyes Romero, A., Ruiz-Moreno, A.J., Groves, M.R., Velasco-Velázquez, M., \& Dömling, A. (2020). Benchmark of Generic Shapes for Macrocycles. Journal of Chemical Information and Modeling, 60(12), 6298-6313. https://doi.org/10.1021/acs.jcim.0c01038

Ribeiro, S., Moura, R.G., Stenert, C., Florín, M., \& Maltchik, L. (2020). Land use in Brazilian continental wetland Ramsar sites. Land Use Policy, 99. https://doi.org/10.1016/j.landusepol.2020.104851

Richter, T.V, Shestakova, L.G., Zentsova, I.M., \& Sugrobova, N.Y. (2020). Using mobile learning applications for the development of students' universal competencies: Evaluation of the effectiveness. Science for Education Today, 10(6), 181-199. https://doi.org/10.15293/2658-6762.2006.10

Riyadi, B.S., Alhamda, S., Airlambang, S., Anggreiny, R., Anggara, A.T., \& Sudaryat. (2020). Environmental damage due to hazardous and toxic pollution: A case study of citarum river, west java, Indonesia. International Journal of Criminology and Sociology, 9, 1844-1852. https://doi.org/10.6000/19294409.2020.09.211

Rizova, E., Bekar, M., \& Velkovski, Z. (2020). Educational challenges of roma minorities: The case of the republic of north macedonia. International Journal of Cognitive Research in Science, Engineering and Education, 8(3), 113-122. https://doi.org/10.23947/2334-8496-2020-8-3-113-122

Rodrigo-Alarcón, J., Parra-Requena, G., \& Ruiz-Ortega, M.J. (2020). Cognitive social capital and absorptive capacity as antecedents of entrepreneurial orientation: a configurational approach. Eurasian Business Review, 
10(4), 493-517. https://doi.org/10.1007/s40821-020-00169-3

Rodríguez-Araya, R., Carranza-Marchena, P., Bulgarelli-Bolaños, R., Ulate-Oviedo, S., \& Camacho-Oviedo, M. (2020). The interdisciplinary work among the base teams of professionals in a pedagogical project for institutionalized children in the children national protection system (patronato nacional de la infancia) [O trabalho interdisciplinar das equipes de base do Projeto Pedagógico para pessoas menores de idade em abrigos do Patronato Nacional de la Infancia]. Revista Electronica Educare, 24(3). https://doi.org/10.15359/REE.243.8

Rodriguez, J.-M.G., Bain, K., \& Towns, M.H. (2020). Graphical Forms: The Adaptation of Sherin's Symbolic Forms for the Analysis of Graphical Reasoning Across Disciplines. International Journal of Science and Mathematics Education, 18(8), 1547-1563. https://doi.org/10.1007/s10763-019-10025-0

Rusdiyanto, Agustia, D., Soetedjo, S., \& Septiarini, D.F. (2020). The effect of cash turnover and receivable turnover on profitability $\mid$ El efecto de la rotación de efectivo y la rotación de cuentas por cobrar en la rentabilidad. Opcion, 36(Special Ed), 1417-1432.

Rusdiyanto, Hidayat, W., Tjaraka, H., Septiarini, D.F., Fayanni, Y., Utari, W., Waras, Indrawati, M., Susanto, H., Tjahjo, J.D.W., Mufarokhah, N., Susetyorini, Elan, U., Samsi, N., Choiri, Syamsul, M., Widodo, M., Suyanto, H., Zainal, M., \& Imanawati, Z. (2020). The effect of earning per share, debt to equity ratio and return on assets on stock prices: Case study Indonesian. Academy of Entrepreneurship Journal, 26(2).

Saldaña, J.J. (2006). Introduction: The latin american scientific theater. In Science in Latin America. https://www.scopus.com/inward/record.uri?eid=2-s2.080052404876\&partnerID=40\&md5=c5babd634f2e2ba3f562e 5 da583f 9875

Saleh, I., Afifa, M.A., \& Alsufy, F. (2020). Does Earnings Quality Affect Companies‘ Performance? New Evidence from the Jordanian Market. Journal of Asian Finance, Economics and Business, 7(11), 33-43. https://doi.org/10.13106/jafeb.2020.vol7.no11.033

Sampson, H., Turgo, N., Cadge, W., Gilliat-Ray, S., \& Smith, G. (2020). Harmony of the Seas?: Work, faith, and religious difference among multinational migrant workers on board cargo ships. Ethnic and Racial Studies, 43(16), 287-305. https://doi.org/10.1080/01419870.2020.1776362

Sangwan, R.S., Jablokow, K.W., \& Defranco, J.F. (2020). Asynchronous Collaboration: Bridging the Cognitive Distance in Global Software Development Projects. IEEE Transactions on Professional Communication, 63(4), 361-371. https://doi.org/10.1109/TPC.2020.3029674

Sarro, R., María Mateos, R., Reichenbach, P., Aguilera, H., Riquelme, A., Hernández-Gutiérrez, L.E., Martín, A., Barra, A., Solari, L., Monserrat, O., Alvioli, M., Fernández-Merodo, J.A., López-Vinielles, J., \& Herrera, G. (2020). Geotechnics for rockfall assessment in the volcanic island of Gran Canaria (Canary Islands, Spain). Journal of Maps, 16(2), 605-613. https://doi.org/10.1080/17445647.2020.1806125

Sato, Y., Tse, Y.K., \& Tan, K.H. (2020). Managers' risk perception of supply chain uncertainties. Industrial Management and Data Systems, 120(9), 1617-1634. https://doi.org/10.1108/IMDS-01-2020-0049

Savitri, E., Abdullah, N.H.N., Said, J., Syahza, A., \& Musfialdy. (2020). How supply chain moderates the relationship of entrepreneurial orientation, adaptability strategy and government interference with performance? International Journal of Supply Chain Management, 9(4), 355-362. https://www.scopus.com/inward/record.uri?eid=2-s2.085089988252\&partnerID=40\&md5=6805b2711867ccea0a039d7d334367b6

Schnabel, C. (2020). Workplace co-determination in Germany: Prevalence, effects and implications [Betriebliche Mitbestimmung in Deutschland: Verbreitung, Auswirkungen und Implikationen]. Perspektiven Der Wirtschaftspolitik, 21(4), 361-378. https://doi.org/10.1515/pwp-2020-0048

Schneider, T. (2020). Agile, non-hierarchical and self-organised in New Work or overwhelmed by system structures and suppressed group dynamic processes in New Office [Agil, hierarchiefrei und selbstorganisiert im New Work oder überwältigt von Systemstrukturen und unterdrückten gruppendynamischen Prozessen im New Office]. Gruppe. Interaktion. Organisation. Zeitschrift Fur Angewandte Organisationspsychologie, 51(4), 469-479. https://doi.org/10.1007/s11612-020-00546-6

Serebryakov, F.F. (2020). -Correlation is the truth of all existence,\| or interdisciplinarity as a methodological principle of adequate social cognition. International Journal of Criminology and Sociology, 9, 2368-2375. https://doi.org/10.6000/1929-4409.2020.09.286

Serebryakova, T.A., Koneva, I.A., Egorova, T.E., Kostina, O.A., Tikhonina, S.A., Khmelkova, E.V, \& Sheshukova, N.N. (2020). Compatible behavior as an actual problem of modernity. International Journal of Criminology and Sociology, 9, 2192-2197. https://doi.org/10.6000/1929-4409.2020.09.260

Setiadi, P.B., Ursula, R., Rismawati, R., \& Setini, M. (2020). Labour Productivity, Work Experience, Age and Education: The Case of Lurik Weaving Industry in Klaten, Indonesia. Webology, 17(2), 487-502. 
https://doi.org/10.14704/WEB/V17I2/WEB17047

Silva-Romo, G., Mendoza-Rosales, C.C., Campos-Madrigal, E., Centeno-García, E., \& de la Rosa-Mora, O.A. (2020). Geological Sheet Tehuacán 14Q-i-(10), Puebla and Oaxaca states, southern Mexico. Journal of Maps, 16(2), 17-27. https://doi.org/10.1080/17445647.2019.1689373

Singh, S., Naib, S., \& Singh, K. (2020). Wow Momo Foods Pvt. Ltd.: in search of new growth drivers. Emerald Emerging Markets Case Studies, 10(4), 1-25. https://doi.org/10.1108/EEMCS-02-2020-0034

Singh, T., \& Malhotra, S. (2020). Workforce analytics: Increasing managerial efficiency in human resource. International Journal of Scientific and Technology Research, 9(1), 3260-3266. https://www.scopus.com/inward/record.uri?eid=2-s2.085078732809\&partnerID=40\&md5=ed78adc5c489b10eadc59bcfdf002089

Stojanov, T., \& Ding, X. (2015). Supplier selection for mixed-model production: A case study from the apparel industry. Fibres and Textiles in Eastern Europe, 23(1), 8-12. https://www.scopus.com/inward/record.uri?eid=2-s2.084920040383\&partnerID=40\&md5=fe7f6ab94a45c6a3fadd6161c7469731

Stombelli, V.M. (2020). Corporate Social Responsibility in hospitality: are sustainability initiatives really sustainable? Case examples from CitizenM, Lefay and Six Senses. Worldwide Hospitality and Tourism Themes. https://doi.org/10.1108/WHATT-06-2020-0041

Stubbs, M. (2016). Nutrients in agricultural production: A water quality overview. In Nutrient Pollution From Agricultural Production: Overview, Management and a Study of Chesapeake Bay. https://www.scopus.com/inward/record.uri?eid=2-s2.085021973181\&partnerID=40\&md5=69a9160cf9fa67b9514b76c7b0ac6f48

Subramanien, D. C., \& Joseph, J. L. (2019). The right to strike under the labour relations act 66 of 1995 (LRA) and possible factors for consideration that would promote the objectives of the LRA. Potchefstroom Electronic Law Journal, 22. https://doi.org/10.17159/1727-3781/2019/v22i0a4400

Suhud, U., Maulida, E., \& Tarma. (2019). Is it male or female? Exploring brand association and personification of a textile-based tourism destination. African Journal of Hospitality, Tourism and Leisure, 8(4). https://www.scopus.com/inward/record.uri?eid=2-s2.085070494559\&partnerID=40\&md5=a5b4f6a7180988319b972df0307865fc

Sun, H., Shi, Y., Li, W., Feng, Z., \& Jiang, D. (2020). Integrated survey of natural resources and comprehensive research of resources science [自然资源综合考察与资源科学综合研究]. Dili Xuebao/Acta Geographica Sinica, 75(12), 2610-2619. https://doi.org/10.11821/dlxb202012005

Susanto, E. (2020). Does love of money matter for innovative work behavior in public sector organizations? Evidence from Indonesia. International Journal of Public Sector Management, 34(1), 71-85. https://doi.org/10.1108/IJPSM-01-2020-0028

Syafii, M., Ulum, B., Rusdiyanto, Suparman, P., Rahayu, D.I., \& Syasindy, N.B. (2020). The effect of financial performance on the company's share price: A case study Indonesian. European Journal of Molecular and Clinical Medicine, 7(8), 1055-1071. https://www.scopus.com/inward/record.uri?eid=2-s2.085098454552\&partnerID=40\&md5=10d4ddcf32dd4bf918ba3622c11e86dd

Syarifuddin, S., \& Damayanti, R.A. (2019). Biodiversity accounting: uncover environmental destruction in Indonesia. Social Responsibility Journal, 16(6), 809-825. https://doi.org/10.1108/SRJ-11-2018-0291

Szlang, J., \& Bruch, H. (2020). Ambidextrous leadership climate - a success factor in the new working world [Ein ambidextres Führungsklima - Erfolgsfaktor in der neuen Arbeitswelt]. Gruppe. Interaktion. Organisation. Zeitschrift Fur Angewandte Organisationspsychologie, 51(2), 187-197. https://doi.org/10.1007/s11612-02000511-3

Taylor, A. (2020). The effect of emotional labour on english teachers in Japan. Issues in Educational Research, 30(4), 1539-1557. https://www.scopus.com/inward/record.uri?eid=2-s2.085097390445\&partnerID=40\&md5=604ed68422391543898a7fee318fee4e

Taylor, S.R., \& Weiss, J.S. (2009). Review of insomnia pharmacotherapy options for the elderly: Implications for managed care. Population Health Management, 12(6), 317-323. https://doi.org/10.1089/pop.2008.0047

Teasdale, R., Ryker, K., Viskupic, K., Czajka, C.D., \& Manduca, C. (2020). Transforming education with community-developed teaching materials: evidence from direct observations of STEM college classrooms. International Journal of STEM Education, 7(1). https://doi.org/10.1186/s40594-020-00251-2

Thakur, S.P. (1999). Size of investment, opportunity choice and human resources in new venture growth: Some typologies. Journal of Business Venturing, 14(3), 283-309. https://doi.org/10.1016/S0883-9026(98)00002-0

Thamagasorn, M., \& Pharino, C. (2019). An analysis of food waste from a flight catering business for sustainable food waste management: A case study of halal food production process. Journal of Cleaner Production, 228, 
845-855. https://doi.org/10.1016/j.jclepro.2019.04.312

Toscano, F., \& Zappalà, S. (2020). Social isolation and stress as predictors of productivity perception and remote work satisfaction during the COVID-19 pandemic: The role of concern about the virus in a moderated double mediation. Sustainability (Switzerland), 12(23), 1-14. https://doi.org/10.3390/su12239804

Tryma, K., Karaman, K., Parlyk, V., \& Svietlakova, M. (2020). Transformation of the political parties of the eu member states. International Journal of Criminology and Sociology, 9, 2224-2234. https://doi.org/10.6000/1929-4409.2020.09.265

Tsitsovits, I. (2020). Neoliberalism's -official crap artll? Sentimental humanism and the work of Tom McCarthy. English Text Construction, 13(2), 109-131. https://doi.org/10.1075/etc.00037.tsi

Tuor Sartore, S.N., \& Backes-Gellner, U. (2020). Educational diversity and individual pay: the advantages of combining academic and VET graduates in the workplace. Empirical Research in Vocational Education and Training, 12(1). https://doi.org/10.1186/s40461-020-00099-4

Turanina, N.A., Murashko, O.Y., Kulyupina, G.A., Zamanova, I.F., \& Perepelkin, I.N. (2020). Scientific school image development of a university based on the system of public relations. International Journal of Criminology and Sociology, 9, 1935-1938. https://doi.org/10.6000/1929-4409.2020.09.226

Vaithyasubramanian, S., Paul, M.J., Babu, R.D., \& Kirubhashankar, C.K. (2020). Job Morale - Employees Energy Driven Tool for Better Productivity in Automotive Industry. Webology, 17(2), 621-630. https://doi.org/10.14704/WEB/V17I2/WEB17056

Valenti, A., \& Horner, S.V. (2020). Leveraging board talent for innovation strategy. Journal of Business Strategy, 4l(1), 11-18. https://doi.org/10.1108/JBS-12-2018-0207

Valenti, M., Brown, E.L., Horner, C.G., Mahatmya, D., \& Colditz, J. (2019). Pathways to working alliances: Special educators' emotional labor and relationships with students with emotional and behavioral disorders. Teachers College Record, 121(7). https://www.scopus.com/inward/record.uri?eid=2-s2.085090435911\&partnerID=40\&md5=d5458e23e8c1eb2bd5f0bda76da553a9

Vasiljeva, M., Ponkratov, V., Volkova, T., Khairova, S., Nikitina, N., Dudnik, O., Alimova, M., Kuznetsov, N., \& Elyakova, I. (2020). The development of scientific activity in Russian universities. Journal of Open Innovation: Technology, Market, and Complexity, 6(4), 1-18. https://doi.org/10.3390/joitmc6040110

Velicu, I., \& Barca, S. (2020). The Just Transition and its work of inequality. Sustainability: Science, Practice, and Policy, 16(1), 263-273. https://doi.org/10.1080/15487733.2020.1814585

Victoria, B.C., \& Ortigosa, J.F.L. (2020). Territory and materiality in the lower valley of the Segura River during the early Late Bronze Age: new data from the settlement of Cobatillas la Vieja (Santomera, Murcia) [Territorio y materialidad en el Bajo Segura durante el Bronce Final inicial: nuevos datos del asentamiento de Cobatillas la Vieja (Santomera, Murcia)]. Cuadernos de Prehistoria y Arqueologia de La Universidad Autonoma de Madrid, 2020(46), 119-140. https://doi.org/10.15366/CUPAUAM2020.46.004

Vidaković, D., Hadzima-Nyarko, M., \& Marenjak, S. (2020). The contribution of workers' attributes on sustainability of construction project realization goals-survey on the impact on productivity in Croatia. Sustainability (Switzerland), 12(23), 1-28. https://doi.org/10.3390/su12239946

Volodko, A., Cockbain, E., \& Kleinberg, B. (2020). -Spotting the signsll of trafficking recruitment online: exploring the characteristics of advertisements targeted at migrant job-seekers. Trends in Organized Crime, 23(1), 7-35. https://doi.org/10.1007/s12117-019-09376-5

Wang, M., Wang, B., \& Abareshi, A. (2020). Blockchain technology and its role in enhancing supply chain integration capability and reducing carbon emission: A conceptual framework. Sustainability (Switzerland), 12(24), 1-17. https://doi.org/10.3390/su122410550

Wiedman, C. (2020). Rewarding Collaborative Research: Role Congruity Bias and the Gender Pay Gap in Academe. Journal of Business Ethics, 167(4), 793-807. https://doi.org/10.1007/s10551-019-04165-0

Wilson, S. (2010). Blowing chunks: Fear Factor, reality television and abjection as a disciplinary practice. Continuит, 24(5), 751-761. https://doi.org/10.1080/10304312.2010.505337

Wolff, S., Brönner, M., Held, M., \& Lienkamp, M. (2020). Transforming automotive companies into sustainability leaders: A concept for managing current challenges. Journal of Cleaner Production, 276. https://doi.org/10.1016/j.jclepro.2020.124179

Wolor, C.W., Khairunnisa, H., \& Purwana, D. (2020). Implementation talent management to improve organization's performance in Indonesia to fight industrial revolution 4.0. International Journal of Scientific and Technology Research, 9(1), 1243-1247. $\quad$ https://www.scopus.com/inward/record.uri?eid=2-s2.085078724866\&partnerID $=40 \& m d 5=a 38 b 21$ e1 ad12029c27f697fee2ca8653

Xiao, M., Cooke, F.L., Xu, J., \& Bian, H. (2020). To what extent is corporate social responsibility part of human resource management in the Chinese context? A review of literature and future research directions. Human 
Resource Management Review, 30(4). https://doi.org/10.1016/j.hrmr.2019.100726

Xu, M., Fan, B., Zhang, Y., Li, A., Li, Y., Lv, M., Shi, Y., Zhu, S., \& Qian, T. (2020). Effects of resource-oriented waste management on optimizing water-food-energy nexus in rural China: A material and energy flow analysis. Journal of Cleaner Production, 276. https://doi.org/10.1016/j.jclepro.2020.124259

Yaghoubi, M., Karamali, M., \& Bahadori, M. (2018). Effective factors in implementation and development of health promoting hospitals: A systematic review. Health Promotion International, 33(3). https://doi.org/10.1093/heapro/day024

Yoshimoto, H., Nakamura, I., \& Kojima, Y. (2020). Clinical characteristics of patients with alcohol dependence comorbid with hypertension among regular drinkers: An internet-based, cross-sectional study in Japan. Alcohol, 89, 147-156. https://doi.org/10.1016/j.alcohol.2020.09.005

Yusuf, F.A. (2020). Effects of lecturer trust on leadership at private universities in Banten. International Journal of Scientific and Technology Research, 9(3), 1448-1451. https://www.scopus.com/inward/record.uri?eid=2-s2.085082620170\&partnerID=40\&md5=33513e516ed8037dafb266b2a28db40f

Zakariya, N.H., Othman, A.K., Abdullah, Z., \& Abdullah, S.S. (2019). The relationship between expatriate adjustment and expatriate job performance at multinational corporations in Malaysia. Academy of Entrepreneurship Journal, 25(Special Issue 2), 1-11. https://www.scopus.com/inward/record.uri?eid=2-s2.085080865896\&partnerID=40\&md5=40cbb5a36fa7822f4d00d6290deba91a

Zhang, Y.E., \& Nesbit, P.L. (2018). Talent Development in China: Human resource managers' perception of the vale of the MBA. International Journal of Management Education, 16(3), 380-393. https://doi.org/10.1016/j.ijme.2018.06.001

Zhylenko, T.I., Kudryavtsev, A.M., \& Zakharkevich, O.V. (2019). Mobile application to calculate the parameters of top wear basic design [МОБИЛЬНОЕ ПРИЛОЖЕНИЕ ДЛЯ РАСЧЕТА ПАРАМЕТРОВ БАЗОВОЙ КОНСТРУКЦИИ ПЛЕЧЕВОЙ ОДЕЖДЫ]. Science and Innovation, 15(3), $24-34$. https://doi.org/10.15407/scine15.03.024 